\section{Pre-breeding in Passiflora subrotunda Mast.: Morphological and Reproductive Characterization at Different Light Levels}

\author{
Viviane de Oliveira Souza, Margarete Magalhães Souza', \\ Alex-Alan Furtado de Almeida, and Joedson Pinto Barroso \\ Department of Biological Sciences, State University of Santa Cruz, Ilhéus \\ 45662-900, Brazil
}

\begin{abstract}
Alexandre Pio Viana
Centre for Agricultural Sciences and Technology, State University of North Fluminense Darcy Ribeiro, Campos dos Goytacazes 28013-602, Brazil
\end{abstract}

\section{Cláusio Antônio Ferreira de Melo}

Department of Biological Sciences, State University of Santa Cruz, Ilhéus 45662-900, Brazil

Additional index words. ornamental Passiflora, irradiance, morphological characteristics, pollen grain viability, stigma receptivity, reproductive system

\begin{abstract}
Passiflora are ornamental plants that are appreciated as part of outdoor decor, composing pergolas and gardens, as well as in interior ornamentation where species tolerant to environments with less light availability are used. The objective of this study was to evaluate the influence of different levels of light and pot types on morphological and reproductive characteristics in Passiflora subrotunda and to support genetic breeding programs of ornamental passifloras. The conditions of $75 \%$ and $100 \%$ light favored vegetative morphological characteristics through the time (105 days). Floral characteristics also presented higher values along increasing light levels. All qualitative characters related to flower and plant coloration did not vary among genotypes. The species possesses diurnal anthesis and flowers throughout the year. Plants cultivated in concrete pots showed greater growth and flower production. Pollen grains (PGs) are large, with an isopolar form, a small polar area, and a long aperture, and amylaceous. Percentage of viable PG was high: above $97 \%$ using Alexander solution and reaching up to $91 \%$ with fluorescein diacetate. Stigmas were partially receptive during the flower's opening period. Percentage of self-compatibility was lower, based on the higher fertilization rate through cross-pollination. These information will be used in planning of ornamental Passiflora-breeding programs, assisting in the selection of characteristics and breeding methods.
\end{abstract}

Genus Passiflora L. belongs to the family Passifloraceae A.L. de Jussieu ex Kunth and includes species known as passion fruit (Passiflora edulis Sims) or passion flowers. Brazil constitutes one of the largest centers of genetic diversity for this genus, with more than 130 species (Bernacci et al., 2013)

\footnotetext{
Received for publication 16 Nov. 2017. Accepted for publication 29 Mar. 2018

We would like to thank UESC, CNPq (Conselho Nacional de Desenvolvimento Científico e Tecnológico), and FAPESB (Fundação de Amparo à Pesquisa do Estado da Bahia) for the financial support for research; CAPES (Coordenação de Aperfeiçoamento de Pessoal de Nível Superior) for the scholarships granted to the first author; $\mathrm{CNPq}$ for the scholarship awarded to the second author.

We also thank the Instituto Plantarum (SP/Brazil) for donating the seeds.

${ }^{1}$ Corresponding author. E-mail: souzamagg@yahoo. com.br.
}

which are in a privileged condition in terms of their genetic resources, which can be used in genetic improvement programs (Meletti et al., 2000).

Cultivating passion fruits have been carried out for the purposes of food production, juices, jams, jellies, and for medicinal purposes because many species produce phytotherapeutic compounds. Interest regarding this genus for ornamentation is steadily growing; this is the result of their beautiful flowers, varying in size, shape, and color, and its great ornamental potential (Abreu et al., 2009). Plants can be put in pots, placed indoors for decoration (Peixoto, 2005), or be used as a living fence, walls, pergolas, or in garden ornamentation (Ulmer and MacDougal, 2004; Vanderplank, 2000). Solar radiation is one of the environmental factors that most influence the growth of species, the distribution of plant species in several ecosystems (Valladares and Niinemets, 2008) and the production of flowers is characterized by light quality, duration, and intensity (Hopkins, 1999). Light intensity can affect photosynthesis, limiting or optimizing plant's growth, development, and the flower production, depending on the species (Pires et al., 2011; Santos et al., 2012b).

One important step during genetic breeding programs is the morphological characterization of the species based on quantitative and qualitative descriptors. These descriptors assist in the identification of genotypes that have characteristics required by ornamental plant market. Such studies make possible to identify duplicated accessions and modes of reproduction that are prevalent in the accessions (Valls, 2007). Morphological characterization has been already performed in some species of Passiflora such as P. edulis f. flavicarpa O. Deg (Negreiros et al., 2007), Passiflora sublanceolata MacDougal (ex Passiflora palmeri var. sublanceolata Rose), Passiflora foetida var. foetida L. (Santos et al., 2011), Passiflora alata Curtis, and Passiflora cincinnata Mast (Lawinscky et al., 2014), and in 61 species of Passiflora L. (Ocampo and Coppens d'Eeckenbrugge, 2017).

Knowledge regarding the biology of a specie's reproduction is a fundamental step toward achieving greater efficiency in genetic breeding and conservation programs because methods applied are distinct and specific, depending on the mode of reproduction prevalent in the population (Ferreira et al., 2004; Ocampo et al., 2016; Silva et al., 2001). In this sense, targeted studies can be performed to indicate the reproduction system and to generate knowledge aimed at the developing superior genotypes. In addition to analyses regarding natural and controlled pollination, detailed investigations are performed such as the number of PGs per anther, PG viability, stigma receptivity, and pollen tube growth (Cruden and MillerWard, 1981).

Pre-breeding involves identifying characteristics and genes of interest in materials that have not gone through any improvement processes, such as wild relatives, local breeds, and their subsequent incorporation in agronomically adapted elite materials (Nass and Paterniani, 2000). In this way, pre-breeding is characterized as a promising alternative to connect research activities in plant genetic resources and breeding programs (Tombolato et al., 2004).

Pre-breeding activities in ornamental species involve the collection of plant material; its introduction, acclimatization, and characterization by the Active Germplasm Bank (AGB), aiming to select genotypes with characteristics of ornamental interest; and inserting genes to build tolerance or resistance to factors that are adverse to cultures (Tombolato et al., 2004). These studies were focused toward alstroemeria (Alstroemeria spp.), gladiolus (Gladiolus spp.), daylily (Hemerocallis spp.), amaryllis (Hippeastrum spp.), and anthurium (Anthurium Anthurium Lind1.) species (Tombolato et al., 2004). Research on species of Passiflora was performed to obtain interspecific hybrids that group characteristics of interest. More than 
400 hybrids have been obtained and recorded in the Passiflora Society International (http:// www.passionflow.co.uk/reg.htm; http://www. passiflorasociety.org/), which include $P$. 'Alva' \#120 (2008), P. 'Aninha' \#121 (2008), P. 'Priscilla' \#122 (2008) (Santos et al., 2012a), P. 'Gabriela' \#170 (2010), and P. 'Bella' \#171 (2010) (Belo, 2010), obtained in Brazil. However, to ensure that genetic diversity is explored, it is necessary to characterize and document genotypes for use in breeding programs (Borém and Miranda, 2009).

Passiflora subrotunda Mast. belongs to the subgenus Passiflora, suppository Stipulata, and section Granadillastrum (Ulmer and MacDougal, 2004). It is an endemic species of Brazil, with geographic distribution in the Northeast region, generally in places of beach (www.brazilplants.com). It is a demanding species of light, requiring greater irradiance for increasing flower production. Passiflora subrotunda was selected for this study because of the intense color of their flowers, which means that they are used in ornamental plant agribusiness. In addition, there is no knowledge about the morphological and reproductive characteristics of this species grown in environments with different levels of light. Thus, the objective of this study was to evaluate the influence of different levels of light and pot types in morphological and reproductive characteristics in $P$. subrotunda, to support genetic breeding programs of ornamental passifloras.

\section{Material and Methods}

Plant material and cultivation conditions. The experiment was conducted between Jan. and July in 2013 at the campus of the State University of Santa Cruz (UESC), Ilhéus, Bahia, Brazil (lat. $39^{\circ} 10^{\prime} \mathrm{W}$, long. $14^{\circ} 39^{\prime} \mathrm{S}$; $78 \mathrm{~m}$ ). Two genotypes were used (G1 and G2) from the species $P$. subrotunda (Fig. 1); these were obtained from seeds donated by the Institute Plantarum, collected in Fortaleza, $\mathrm{CE}$, and kept in AGB (AGB-Passifloras) in the UESC.

To obtain the replications, cuttings were taken from median part of the branches of a plant matrix from each genotype and placed in black $1.5 \mathrm{~L}$ polyethylene bags, containing washed sand for rooting. After new leaves had appeared, the cuttings were transferred to $45 \mathrm{~L}$ concrete and ceramic pots, which had been filled with sieved soil (a horizon sandclay soil) and placed in artificial shading. The differing light levels were obtained by the use of black plastic "shading" screens fixed in wooden frames with a total area of $5 \times 5 \times$ $2 \mathrm{~m}^{3}$. These structures permitted $25 \%, 50 \%$, $75 \%$, and $100 \%$ of light incidence. The choice regarding the types of pots used was based on previous studies, which are contrasting to the cultivation of ornamental passifloras (Santos et al., 2012b). Fertilization was performed using micronutrients (boric acid, ammonium molybdate, zinc sulfate, magnesium sulfate, and copper sulfate) and macronutrients [urea, MAP, and potassium chloride $(4 \mathrm{~N}-14 \mathrm{P}-8 \mathrm{~K})$ ] every $60 \mathrm{~d}$. The values
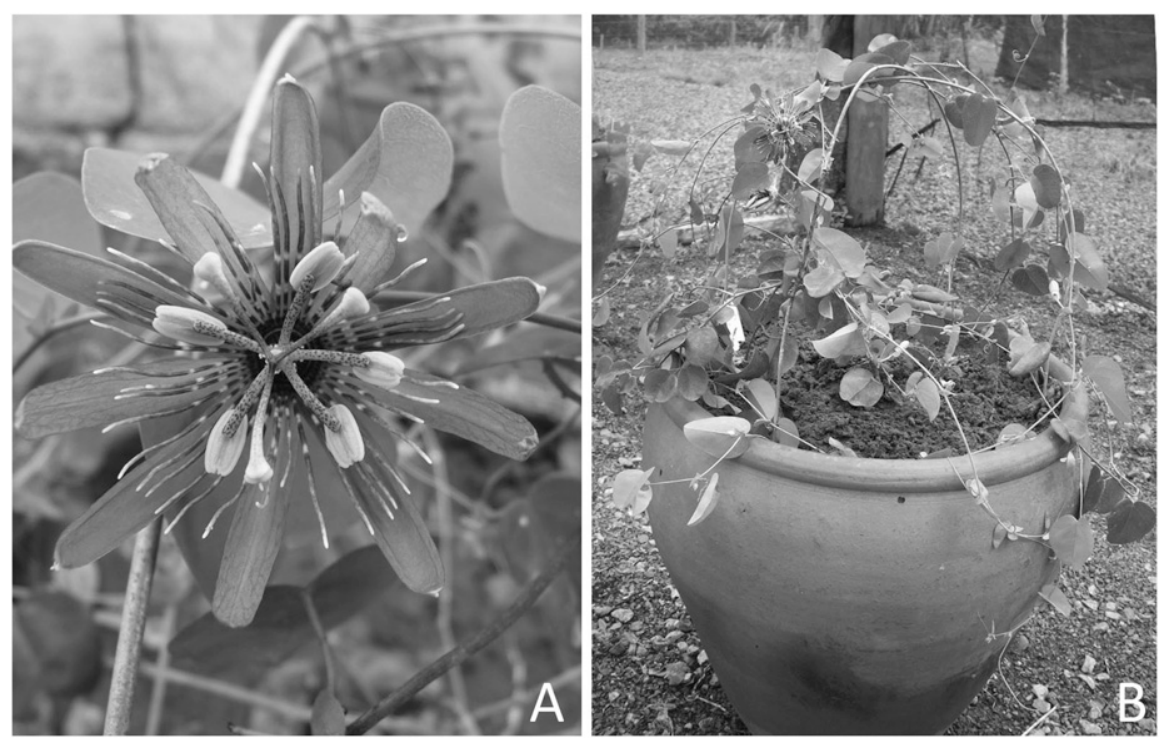

Fig. 1. Passiflora subrotunda: flower (A) and growth habit (B).

of photosynthetically active radiation $(999.25$ umol photons $\mathrm{m}^{-2} \cdot \mathrm{s}^{-1}, 100 \%$ light; 643.12 umol photons $\mathrm{m}^{-2} \cdot \mathrm{s}^{-1}, 75 \%$ light; $497.25 \mu \mathrm{mol}$ photons $\mathrm{m}^{-2} \cdot \mathrm{s}^{-1}, 50 \%$ light; and $285.12 \mu \mathrm{mol}$ photons $\mathrm{m}^{-2} \cdot \mathrm{s}^{-1}, 25 \%$ light) were obtained using a portable sensor light radiation BQMSUN (Apogee, EUA). The values of relative humidity $(88.97 \%$ to $100 \%$ light, $89.00 \%$ to $75 \%$ light, $85.05 \%$ to $50 \%$ light, and $84.76 \%$ to $25 \%$ light $)$ and air temperature $\left(26.90{ }^{\circ} \mathrm{C}, 100 \%\right.$ light; $26.20{ }^{\circ} \mathrm{C}, 75 \%$ light; $25.54{ }^{\circ} \mathrm{C}, 50 \%$ light; and $25.73{ }^{\circ} \mathrm{C}, 25 \%$ light) were obtained by Professional Touch Screen Weather Center with PC interface model WH-1081PC (Fine Offset Electronics Co., China), which remained within the different environments with available light.

Morphological characteristics. Morphological characterization was performed using morphological descriptors, 29 of these being quantitative and nine qualitative. Characteristics according to official descriptors of ornamental Passiflora were included in the analyses (MAPA, 2008) and some that were not from the list, but rather from previous analyses (Santos et al., 2011). The quantitative descriptors evaluated were as follows: length of the first series of filaments of the corona $(\mathrm{C} 1)$ in $\mathrm{cm}$, length of the second series of filaments of the corona $(\mathrm{C} 2)$ in $\mathrm{cm}$, petal length $(\mathrm{PL})$ in $\mathrm{cm}$, petal width $(\mathrm{PW})$ in $\mathrm{cm}$, sepal length (SL) in cm, sepal width in $\mathrm{cm}$, bract length in $\mathrm{cm}$, bract width (BW) in $\mathrm{cm}$, corona diameter (CD) in $\mathrm{mm}$, flower diameter (FD) in $\mathrm{mm}$, number of flowers/plant, internodes numbers, stem diameter (SD) in $\mathrm{mm}$, length of the main branch (LM) in $\mathrm{cm}$, number of leaves/plant, leaf width in $\mathrm{cm}$, leaf length (LL) in $\mathrm{cm}$, polar axis (PA), equatorial axis (EA) in $\mu \mathrm{m}$, colpo width in $\mu \mathrm{m}$, mesocolpium in $\mu \mathrm{m}$, polar view (PV) in $\mu \mathrm{m}$, apocolpium in $\mu \mathrm{m}$, murus in $\mu \mathrm{m}$, lumen (LU) in $\mu \mathrm{m}$, mesh, polar area index (PAI) in $\mu \mathrm{m}$, and polar axis/ equatorial axis ratio $(\mathrm{P} / \mathrm{E})$. The qualitative descriptors evaluated were as follows: predominant period of anthesis, staining corona, coloration of the perianth, staining of pollen, chlorination of the stamen, staining stiletto, staining of stigma, leaf color, and coloring branch. The evaluations were performed $111 \mathrm{~d}$ after treatments, between January and April, and included a total of 105 observation days (16 weeks). Quantitative data were obtained with the use of a digital caliper and ruler. Qualitative characteristics related to color were based on the Munsell Plant Tissue Color Chart (Munsell, 1981).

Pollen grains were collected from anthesis flowers, mounted on stubs on doublesided graphite adhesive tape, and placed in a desiccator for $3 \mathrm{~d}$. The samples were metallized with gold and observed in a scanning electron microscope (SEM). Ten measurements were taken of 11 pollen characters which were obtained from the SEM images at the Electron Microscopy Center at the UESC. Pollen grain classification was performed based on the relationship between the $\mathrm{P} / \mathrm{E}$ (Erdtman, 1945, 1952). Pollen grains were also classified based on PAI, which is given by the relationship between the extremities of the two adjacent apertures (or their margins) and the greatest width of the PG in PV, according to the classification proposed by Iversen and TroelsSmith (1950) and Faegri and Iversen (1964).

\section{Reproductive characteristics.}

Pollen grain viability potential Pollen grains from anthesis flowers were collected at nine different time periods, with a $1-\mathrm{h}$ interval between them, beginning at 9:00 AM and ending at 5:00 PM, in all light levels. The following chemical tests were performed: a) Alexander solution (Alexander, 1969), to test the reactivity of the wall and cytoplasm; the PG considered viable were those whose cytoplasm remained stained and intact; and b) fluorescein diacetate (Heslop-Harrison and Heslop-Harrison, 1970), to detect the esterase activity and plasmalemma integrity of the vegetative cell. For each anther were counted the numbers of viable and unviable PG for each collection time. Using Alexander solution, the unviable PG were classified as type 1 
(T1), empty (absence of cytoplasm), type 2 (T2), contracted cytoplasm (Souza et al., 2004a), type 3 (T3), giant (with a size double that of viable GP), and type 4 (T4) micrograin (very small, with the absence of cytoplasm, nucleus, or both). Lugol solution (Johansen, 1940) was only used to detect reserve substance (starch) in the PG because some passifloras have amylaceous PG (Souza et al., 2004a), with the presence of starch being considered positive when stained dark blue or brown.

Stigma receptivity. A chemical test with 3\% hydrogen peroxide + benzidine (Galen and Plowright, 1987) was performed to indicate the presence of peroxidase. Stigmas were collected at 1-h intervals, beginning at 9:00 $\mathrm{Am}$ and ending at 5:00 $\mathrm{PM}$, in all light levels, then immediately transferred to glass containers with the test solution where stigmas remained totally immersed. The stigmas were subsequently observed in a stereoscopic microscope and classified as follows: a) receptive, those which presented dark blue staining of the stigmatic papillae; b) partially receptive, those which only presented some regions of stained stigma; and c) unreceptive, those which presented staining in less than $30 \%$ of the stigmatic surface. To control the test's effectiveness, stigmas at early formation were used (flower buds less than $1.0 \mathrm{~cm}$ in size) because of reproductive cells not being fully formed. Damaged or injured stigmas were not used to avoid falsepositive reactions.

Aspects of the reproduction system. For the controlled crossings, the following treatments were performed: open pollination, manual self-pollination, and controlled crosspollination. Five flowers from two genotypes of $P$. subrotunda were used for each treatment, with six repetitions, totaling 60 flowers. To estimate the self-fertility percentage related to open pollination, flower buds closed were marked with plastic labels and fruits at early stage of development were observed. Flower buds were protected with paper bags before anthesis for the estimative of self-fertility toward controlled self-pollination. At the opening time, flowers were manually selfpollinated with the aid of tweezers and protected once again. Crossed controlled pollination was estimated using emasculated flowers before anthesis. At the anthesis period, the stigmas were manually pollinated with pollen collected from a different individual, and then flowers were again protected. For all treatments, pollinated flowers were labeled and, $5 \mathrm{~d}$ after pollination, the self-fertility was verified. The number of fruits originating from the pollinations was recorded and the fruits were covered with a nylon net for avoiding fall during ripening process. After fruits ripening, the number of seeds was recorded. The obtained data were used to calculate the estimated rate of selfincompatibility; for this proposal, ISI index ("index to measure self-incompatibility") was used: ISI $=$ number of fruits resulting from self-pollination $\div$ number of fruits from cross-pollination (both controlled).
The ISI values (modified by Zapata and Arroyo, 1978) reflect the possibilities: $\geq 1=$ self-compatible; $<1>0.2=$ partially selfcompatible; and $<0.2=$ self-incompatible. The self-fertility rate (no. of fruits) after artificial self-pollination was used to define the classes as follows: self-incompatible $=0 \%$ to $3 \%$, class 0 ; partially self-compatible $=3 \%$ to $30 \%$, class 1 ; and self-compatible $=>30 \%$, class 2 (modified by Zapata and Arroyo, 1978).

Data analysis. Completely randomized experimental design in a factorial scheme $(2 \times 2 \times 4 \times 16)$ was used for vegetative characteristics, corresponding to two genotypes, two types of pots, four light levels, and 16 weeks of evaluation, with three replications. The same design was used for floral characteristics, without considering the evaluation periods. The same design was adopted for pollen viability and stigma receptivity, in factorial scheme $(4 \times 9)$, corresponding to four light levels and nine PG collection periods, with three repetitions (plants). For the reproduction system, the design was also completely randomized in a factorial scheme $(2 \times 3)$, corresponding to two genotypes and three types of pollinations, with six repetitions (plants). Analysis of variance and regression analysis were performed between the analyzed variables. The Duncan test $(P<$ 0.05 ) was applied to compare the averages for pollination data.

\section{Results}

Quantitative morphological characteristics. Significant differences were observed $(P<0.05)$ between genotypes, pots types, light levels, and evaluation periods for vegetative morphological characteristics (Supplemental Table 1). An increase in the number of internodes over time was observed; the G1 subjected to $100 \%$ light and cultivated in a concrete pot presented higher values over 105 evaluation days (Supplemental Fig. 1A), when compared with genotype 2 (Supplemental Fig. 1B). The G2 had the largest number of internodes when cultivated in a concrete pot over 98 evaluation days with $75 \%$ light (Supplemental Fig. 1D). Increased SD was verified, over time, with increasing light levels for both genotypes in both pots used (Supplemental Fig. 1E-H).

Both genotypes showed increased growth of the main branch over time. However, the highest values were obtained by G1 cultivated in a concrete pot and subjected to $75 \%$ light, over the 98 and 105 evaluation days (Supplemental Fig. 1I). Genotype 2 presented the highest LM with $50 \%$ of light and cultivated in a concrete vase over 91, 98, and 105 evaluation days (Supplemental Fig. 1K).

The genotypes (G1 and G2) during the evaluation period presented higher leaf number values under the condition of $75 \%$ light, grown in concrete (Supplemental Fig. 2A) and ceramic pots (Supplemental Fig. 2D). Increasing width and length of the leaves were inversely proportional to increased levels of light for both genotypes, grown in both pots (Supplemental Fig. 2E, G-J). By contrast, the cultivation with $100 \%$ light and in ceramic pots provided larger leaves in $\mathrm{G} 1$ (Supplemental Fig. 2F).

For $\mathrm{CD}$, the length of the first series of corona filaments, and width of sepal, there were no significant differences $(P>0.05)$ (Supplemental Table 2). However, there were significant differences between levels of light for the length of the second series of corona filaments (Supplemental Table 2), which increased as light levels (Supplemental Fig. 3A).

There was interaction between genotypes and light levels and between type of pot and light levels (Supplemental Table 2) for PW. G1 had the largest PW when subjected to $75 \%$ and $100 \%$ light. However, for G2, it was not possible to fit an equation to significantly explain this difference (Supplemental Fig. 3B). The largest PWs were obtained when plants were grown in ceramic pots with $50 \%$ light, but it was not possible to fit an equation to significantly explain the interaction between ceramic pots and light levels (Supplemental Fig. 3C).

For bract width, significant differences were observed $(P \leq 0.05)$ between $\mathrm{G} 1$ and G2, among light levels, as well as the interaction between them (Supplemental Table 2). An increase in BW was verified along with increasing light levels for both genotypes (Supplemental Fig. 3D). Genotype 1 had a greater value when subjected to an environment with full sun (100\% light) (Supplemental Fig. 3D). On the other hand, the greatest BW for $\mathrm{G} 2$ was verified in $75 \%$ light. There was interaction between genotypes, type of pot, and light levels for BL (Supplemental Table 2). There was an increase in BL because of the increased light levels for both genotypes (Supplemental Fig. 3E and F), with G1, cultivated in a ceramic pot, in $100 \%$ light, achieving the greatest length (Supplemental Fig. 3E).

There was interaction between genotypes, type of pot, and light levels for PL (Supplemental Table 2). A reduction in PL was observed along with increasing light levels, with the highest value obtained in $25 \%$ light, in plants cultivated in concrete pots (Supplemental Fig. 3G). However, it was not possible to fit an equation to explain the interaction between G2, the type of pot, or light levels.

Flowers number per plant was influenced by light levels and pots types. Passiflora subrotunda produced a greater numbers of flowers by increasing light levels when cultivated in concrete pots (Supplemental Fig. $3 \mathrm{H})$. There were interactions between genotypes, type of pot, and light levels for FD and SL. There was a reduction in FD (Supplemental Fig. 3I and J) and SL (Supplemental Fig. 3K and L) by increasing light levels, except for G1 grown in ceramic pots (Supplemental Fig. 3I)

Passiflora subrotunda presented PG with diameter equal to $54.35 \mu \mathrm{m}$, being characterized as large. Based on the ratio between the PA and the EA, PG shape was classified as isopolar (oblate spheroidal), with a small 
polar area $(0.35 \mu \mathrm{m})$ and long aperture (Fig. 2B). The PGs presented three pairs of anastomosing colpi at their extremities (syncolpated), forming a ring around the mesocarp (Fig. 2B). Furthermore, PG presented to be reticulated, with ornamentation that consists of walls that surround LUs larger than $1.0 \mu \mathrm{m}$ in diameter (Fig. 2D). The wall is smooth and sinuous, whereas LU presents bacula (Fig. 2D).

Flowering time. Passiflora subrotunda flowering happened throughout the whole year, with greater flowering occurring between January and April. The species presented diurnal anthesis with flowers opening between 8:00 $\mathrm{Am}$ and 9:00 $\mathrm{AM}$, and then closing around 7:00 PM.

Qualitative morphological characteristics. Qualitative characters related to plant and flower did not vary between genotypes: violet coloring of corona (5RP 3/6), violet perianth (5RP 4/4), yellow PG (5Y 8/10), green stamen (5GY 5/2), green leaf (7.5GY 5/8), brown branch (5YR 5/2), green style (5GY 6/4), and sienna sand stigma (5Y 7/4).

Reproductive characteristics.

Pollen grain viability potential. By the Alexander test was observed influence of light levels only for nonviable GP T1 PG $(P \leq 0.05)$, and as light levels increased, there was reduction in the number of T1 PG (Fig. 3A). No interaction between collection time periods and light levels for the percentage of viable PG, unviable PG T2 (Fig. 4B), T3 (Fig. 4C), and T4 (Fig. 4D) (Supplemental
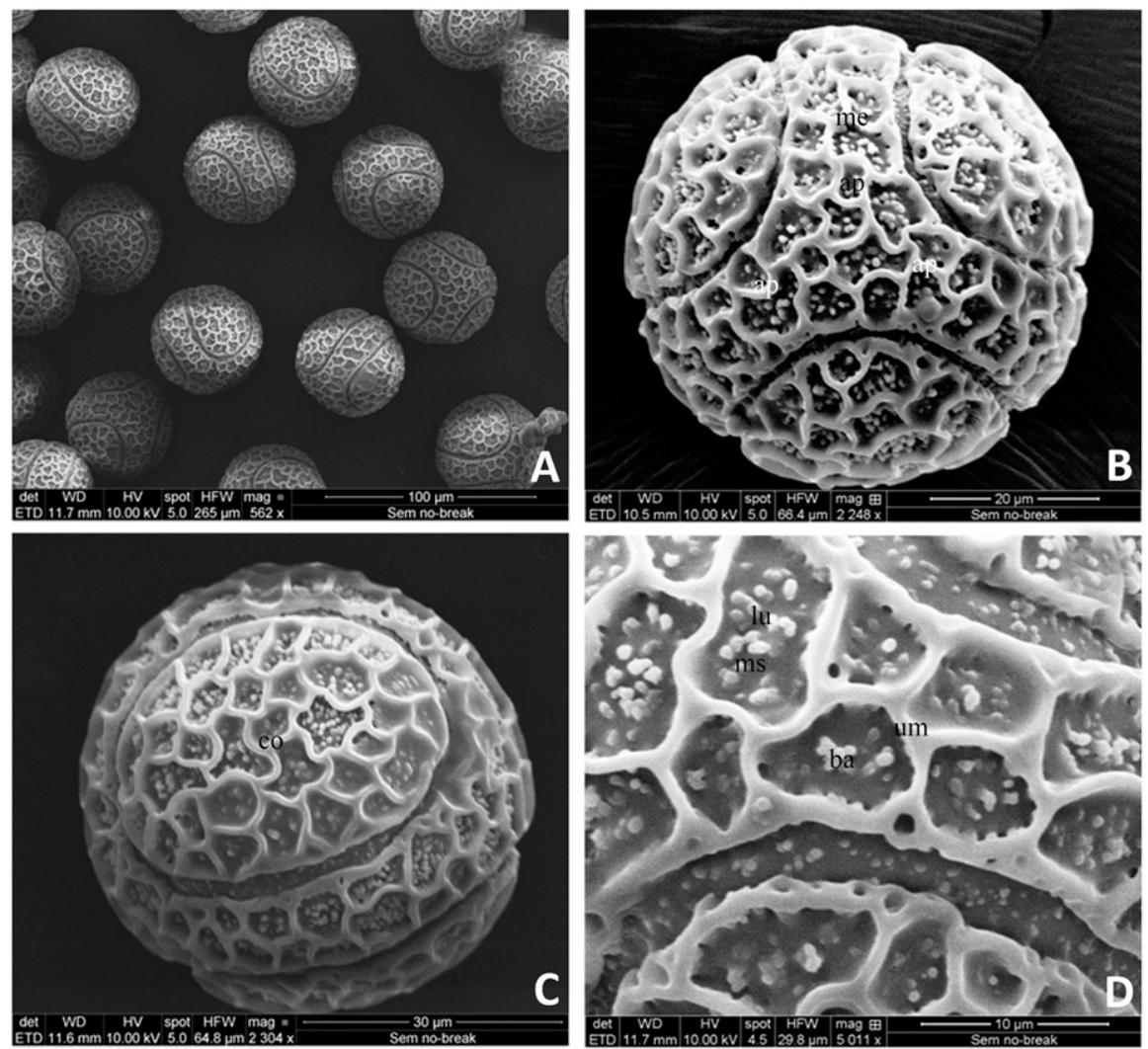

Fig. 2. Pollen morphology of Passiflora subrotunda observed in scanning electron microscope. (A) Intact pollen grains; (B) polar view showing the three pairs of colpi, mesocolpi, and apocolpi; (C) equatorial view; (D) ornamental detail showing the lumen, wall, and mesh. ap = apocolpi; me = mesocolpi; co = colpi; lu = lumen; $\mathrm{ma}=$ mesh; $\mathrm{mu}=$ wall; $\mathrm{ba}=$ bacula .

Table 3) was recorded. The highest percentage of PG T1 was verified on plants subjected to $25 \%$ light (Table 1 ).

Influence of collection times was observed $(P<0.05)$ for percentage of viable and unviable $\mathrm{PG}$, with fluorescein diacetate (Supplemental Table 3; Fig. 4E). There was an increase in the percentage of viable PG as the collection time periods increased (Fig. 3B). The highest percentage was obtained at 3:00 PM (Table 2).

Passiflora subrotunda pollen showed a positive reaction to Lugol's iodine, as the cytoplasm was stained brown (Fig. 4F), thereby confirming the presence of starch as reserve substance.

Stigma receptivity. Stigmas that were used as a control did not respond positively to tests (Fig. 4H), indicating that they were not receptive. There was interaction between light levels and stigma collection time for the receptivity percentage (Supplemental Table 3). The stigmas were found to be totally receptive (Fig. 4I) when P. subrotunda plants were subjected to $100 \%$ (11:00 AM and 1:00 $\mathrm{PM})$ and 50\% (1:00 PM and 4:00 PM) light (Supplemental Fig. 4). When subjected to $100 \%$ light, there was increased receptivity up to 1:00 PM, reducing from this time onward (Supplemental Fig. 4). On the other hand, those species subjected to $25 \%$ light did not present fully receptive stigma (Fig. 4J) at the collection time (Supplemental Fig. 4), with most only being partially receptive.

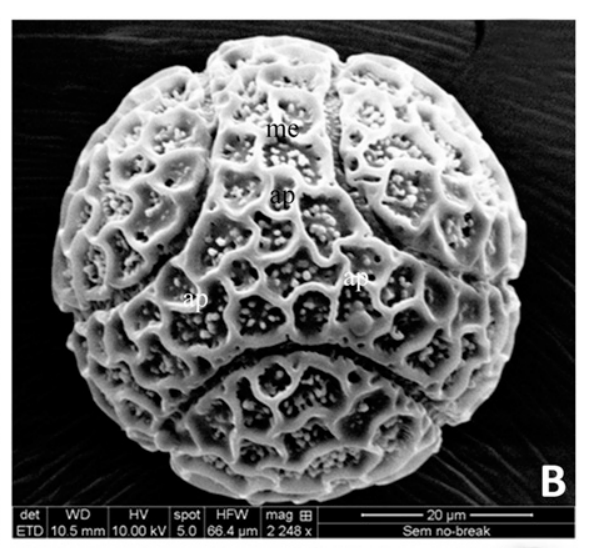
plants subjected to the most elevated light conditions produce photoassimilates more efficiently (Varela and Santos, 1992).

Stem diameter increased as light levels reduced. The same result was verified by Pires et al. (2012) and Santos et al. (2012b), while working with ornamental and hybrid species of Passiflora, respectively. The larger $\mathrm{SD}$ is a desirable parameter for ensuring greater plant support (Dousseau et al., 2007). This increase is directly related to the exchange activity, which in turn is dependent on photosynthetic products such as translocated carbohydrates and hormones from apical regions (Paiva et al., 2003).

The greatest leaves production was verified in those environments that were better lit because increasing numbers of leaves is related to greater light availability, providing greater $\mathrm{CO}_{2}$ absorption and increasing photosynthetic activity (Passos, 1997). In ornamental Passiflora hybrids, increase in the NL 

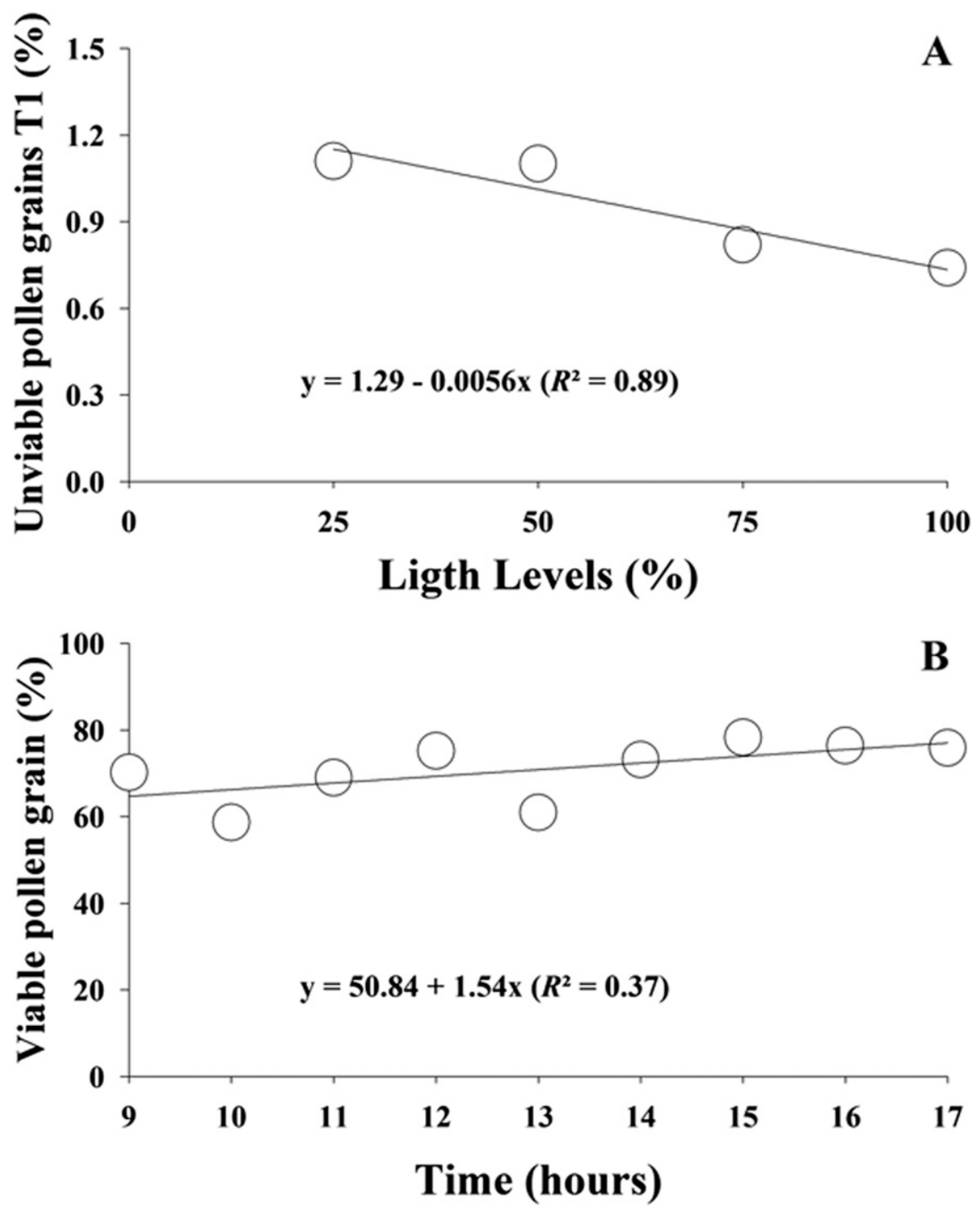

Fig. 3. Pollen grains (PG) percentage type 1 unviable (empty) 1 of (A) Passiflora subrotunda with Alexander solution subjected to different levels of light and percentage of viable PGs (B) with fluorescein diacetate depending on different collection times.

was proportional to the increase on the availability of light (Santos et al., 2012b), reinforcing the results found in this study.

Greater foliar expansion in conditions with lower light availability (25\%) can be justified by the plant's need to expand its photosynthetic surface. This strategy is used to maximize light absorption, developing less thick leaves, a lower leaf mass rate per unit area, and a larger leaf mass fraction per plant (Valladares and Niinemets, 2008). According to carbon-gain hypothesis, plants that are tolerant to low light intensity have greater LLs and widths than species that are not tolerant (Valladares and Niinemets, 2008). In this study, there was increased photoassimilate investment in foliar expansion because those plants subjected to $25 \%$ light had greater LL and width values than those with other light levels. Thus, this species presented phenotypic plasticity, with consequent acclimation to low light intensity, because this is characterized as a species adapted to full sun environments.
The highest light levels favored some floral characteristics of both genotypes, especially in terms of flowering, which gradually increased by light availability, fact also observed in ornamental Passiflora hybrids (Santos et al., 2012b). Greater flower production, provided by intense radiation, could be related to an increased photosynthesis rate because there is a greater production of photoassimilates, allowing greater flower production because of the more energy availability (Cavichioli et al., 2006). These results will assist the use of $P$. subrotunda for a possible crossing, producing a hybrid with characteristics that are desirable for the ornamental plant market. In its turn, FD, PL, and SL were larger in $25 \%$ light, making this an important acclimation mechanism of this species to catch light.

The greater flowering of $P$. subrotunda genotypes grown in concrete pots may be a consequence from less water retention capacity when comparing that container with ceramic pot. As a result, this water limitation availability to the plant induces flowers production. Floral induction, through limiting water availability, may be related to a reduction on the root system growing. This reduction modifies the plant's hormonal balance and may compromise phytohormone biosynthesis (Cruz et al., 2006). Cultivating interspecific hybrids of Passiflora in ceramic pot favored vegetative growth. On the other hand, cultivating in concrete pots favored flowering (Santos et al., 2012b).

Describing $P$. subrotunda PGs morphology has never been done before and its characteristics, in terms of aperture type, colpi numbers, size, shape, and PG ornamentation, are consistent to the genus Passiflora; among them, PG apertures has proved to be an important species identification characteristic. Apertures are regions that delimit releasing material inside the PG (Erdtman, 1986). Based on their shape variation, apertures can be circular, be called pores, or be elongated, with a length greater than their width (elongated), thus being referred as colpi (Martins et al., 2013).

When comparing pollen morphology of 15 species of Passiflora, the species were organized into two groups according to the number and aperture shapes. After the characterization of 15 species, nine (Passiflora actinia, Passiflora eichleriana, Passiflora elegans, Passiflora tenuifila, Passiflora urnifolia, Passiflora amethystina, Passiflora caerulea, $P$. edulis, and $P$. foetida) presented a morphology similar to that of the species under study (Evaldt et al., 2011). These species presented spherical large PG, isopolar with long colpi, distributed in pairs, joined lengthwise at the extremities, forming a ring around the pseudoperculum, with sinuous walls and free bacula inside the LUs (Evaldt et al., 2011).

Pollen grain sizes from Passiflora species can vary (Amela-García et al., 2002; Evaldt et al., 2011). Regarding the species under study, PG was characterized as large, as were those of $P$. caerulea, Passiflora mooreana, $P$. foetida and Passiflora chrysophylla (AmelaGarcía et al., 2002), P. actinia, P. eichleriana, $P$. elegans, $P$. tenuifila, $P$. urnifolia, $P$. amethystina, and $P$. edulis (Evaldt et al., 2011). However, there are Passiflora species which have medium-size PGs, such as Passiflora misera, Passiflora suberosa (AmelaGarcía et al., 2002), and Passiflora morifolia (Evaldt et al., 2011).

Qualitative characteristics. Species of Passiflora have distinct floral opening periods, which are usually short, rarely being more than $8 \mathrm{~h}$, with anthesis and closing time adapted to pollinator activity period (Costa et al., 2009). Plants subjected to higher light levels began flowering before those plants subjected to lower light levels, confirming the importance of light on the flowering process (Santos et al., 2012b). Yellow passion fruit (P. edulis. f. flavicarpa Degener), begin to flower around $12 \mathrm{Am}$ and end at the afternoon. However, purple passion fruit $(P$. edulis $\mathrm{f}$. edulis Sims) flowering can start earlier at the morning, with variation on the flower's 
opening time (Arias et al., 2016; Bruckner et al., 1995; Meletti et al., 1992; Oliveira, 1987; Rendón et al., 2013).
Reproductive characteristics. Studying pollen viability has a great relevance and provides basic information for species

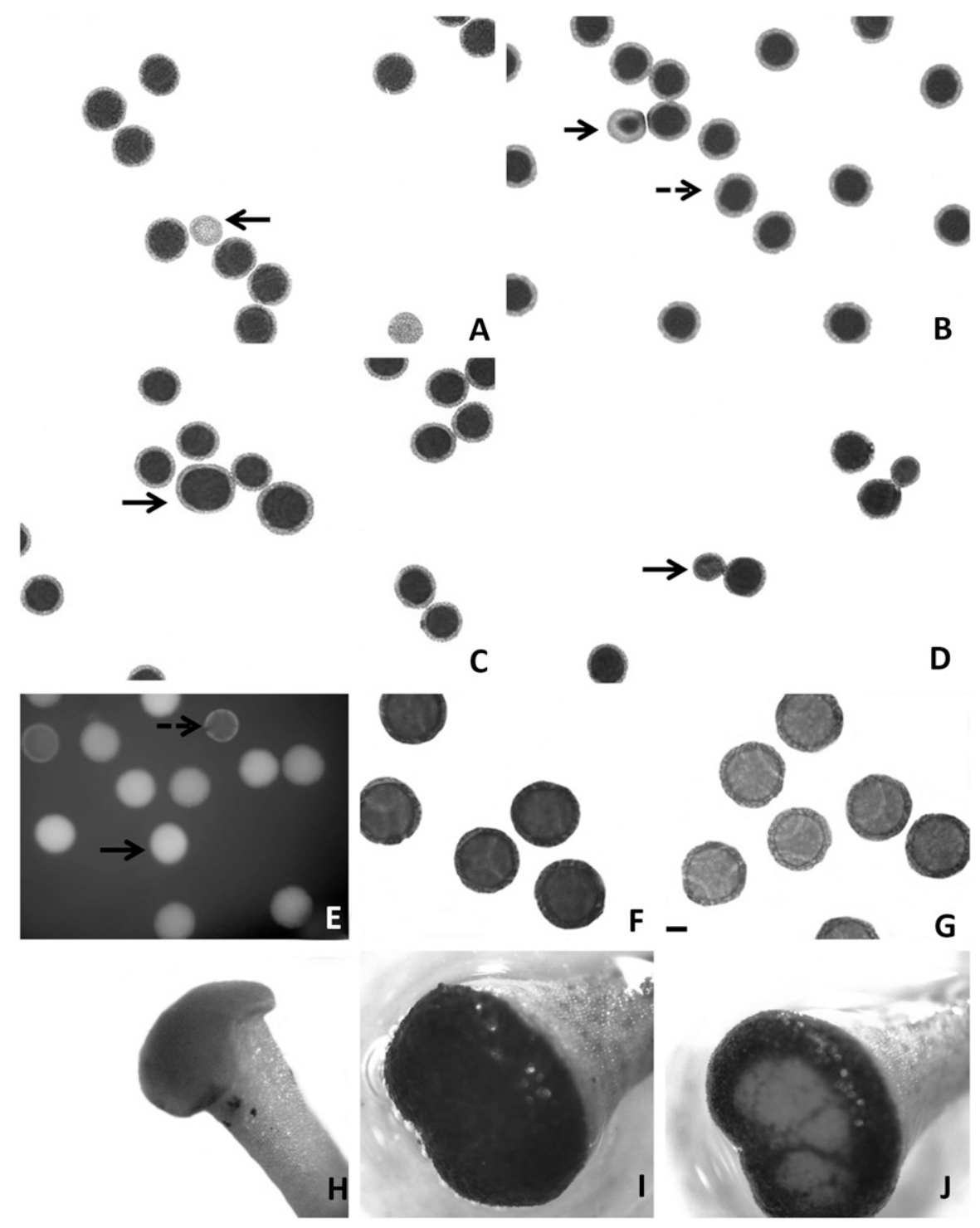

Fig. 4. Pollen grains of Passiflora subrotunda. (A-D) Alexander solution test: (A) PG unviable empty type (arrow), (B) viable PG — red cytoplasm (dashed arrow) and PG unviable the contracted type (arrow), (C) large PG (arrow), and (D) micrograin (arrow); (E) fluorescein diacetate test showing viable PG green fluorescent (arrow) and nonfluorescent unviable (dashed arrow). (F-G) Lugol test: (F) positive reaction (brown color) to starch and (G) negative reaction (light yellow chlorination); $(\mathbf{H}-\mathbf{J})$ of stigma receptivity test: $(\mathbf{H})$ control stigma showing negative reaction, (I) receptive stigma, and (J) partially receptive stigma. Bar $=50 \mu \mathrm{m}$.

conservation and planning genetic breeding programs (Dafni, 1992; Kearns and Inouye, 1993). To initiate a breeding program, the breeder wants high pollen viability because pollen is the means of characteristics transmission to future progenies, improving or promoting new cultivar development (Brito et al., 2010). Pollen viability rate greater than $70 \%$ is considered high for passion fruit (Souza et al., 2002) and reflects a regular meiosis, once plant's meiotic behavior is directly related to fertility degree (DefaniScoarize et al., 1995). Genotype characteristic expression is the result of the contribution provided by the male and female gametes; higher pollen viability promotes greater possibility to originate different allelic combinations and genetic variability (Souza et al., 2002).

Pollen unviability can occur during androsporogenesis, when failures in meiotic function result in gametes with unbalanced or anucleated chromosomes (Twell, 1995), resulting in pollen micrograins, in anucleated PGs with reduced cytoplasm, or in giant PGs (Souza et al., 2004a). However, the action of genes during androgametogenesis is known in some plant species (Singh, 2002), which leads to pollen unviability as a result from PGs with contracted cytoplasm and plasmalemma not sticking to the cell wall (Souza and Pereira, 2011). The unviable pollen formation may also be influenced by the environment in which the plants are found. In $P$. edulis f. flavicarpa, ambient temperature interferes on androsporogenesis, androgametogenesis, and, consequently, on PG viability (Souza et al., 2002), showing that PG viability can also be influenced by the time at which they were collected. There was a reduction on pollen viability in $P$. edulis $\mathrm{f}$. flavicarpa starting from anthesis-12:00 AM to 7:00 $\mathrm{PM}$-showing that pollen viability percentage was negatively influenced by the collection times, with greatest percentage obtained when the flowers began to open (Souza et al., 2002). Values greater than $90 \%$ were found for viable PGs during studies on pollen viability in wild species of Passiflora, with exception of $P$. pentagona Mast., which had $78.2 \%$; contracted or empty unviable PGs were also observed, with a predominance of empty type, indicating meiosis problems (Souza et al., 2004a). In P. sublanceolata,

Table 1. Viable pollen grains percentage using Alexander solution, unviable type 1 (empty), unviable type 2 (contracted), type 3 (micrograin), and type 4 (giant) in Passiflora subrotunda as a function of different light levels and times of collection of the pollen grain.

\begin{tabular}{|c|c|c|c|c|c|c|c|c|c|c|c|c|c|c|c|c|c|c|c|c|}
\hline \multirow{2}{*}{$\mathrm{H}$} & \multicolumn{4}{|c|}{ Light level (\%) } & \multicolumn{4}{|c|}{ Light level (\%) } & \multicolumn{4}{|c|}{ Light level (\%) } & \multicolumn{4}{|c|}{ Light level (\%) } & \multicolumn{4}{|c|}{ Light level (\%) } \\
\hline & 25 & 50 & 75 & 100 & 25 & 50 & 75 & 100 & 25 & 50 & 75 & 100 & 25 & 50 & 75 & 100 & 25 & 50 & 75 & 100 \\
\hline 9 & 98.99 & 97.27 & 98.27 & 98.16 & 0.66 & 1.70 & 0.99 & 1.02 & 0.16 & 0.44 & 0.26 & 0.40 & 0.16 & 0.50 & 0.46 & 0.32 & 0.03 & 0.08 & 0.02 & 0.11 \\
\hline 11 & 98.20 & 98.38 & 8.42 & 98.36 & 0.94 & 1.15 & 0.75 & 0.86 & 0.30 & 0.22 & 0.22 & 0.36 & 0.55 & 0.21 & 0.58 & 0.33 & 0.02 & 0.04 & 0.03 & 0.09 \\
\hline 12 & 97.96 & 98.87 & 98.42 & 98.96 & 1.14 & 0.69 & 0.97 & 0.39 & 0.42 & 0.18 & 0.19 & 0.15 & 0.40 & 0.18 & 0.38 & 0.43 & 0.07 & 0.08 & 0.04 & 0.07 \\
\hline 13 & 98.49 & 98.25 & .24 & .79 & 1.15 & 0.93 & 1.04 & 0.61 & 0.24 & 0.25 & 0.12 & 0.27 & 0.05 & 0.45 & 0.42 & 0.29 & 0.08 & 0.11 & 0.18 & 0.05 \\
\hline 14 & 97.93 & 97.81 & 98.80 & 98.03 & 1.55 & 1.19 & 0.66 & 0.98 & 0.24 & 0.26 & 0.20 & 0.31 & 0.20 & 0.65 & 0.32 & 0.64 & 0.08 & 0.09 & 0.02 & 0.04 \\
\hline 17 & 97.96 & 97.94 & 98.52 & 98.71 & 1.26 & 1.53 & 0.86 & 0.49 & 0.21 & 0.07 & 0.24 & 0.15 & 0.45 & 0.34 & 0.30 & 0.58 & 0.12 & 0.12 & 0.07 & 0.08 \\
\hline
\end{tabular}

PG Vi = Viable pollen grains; Uv PG = unviable pollen grains; T1 Uv PG = unviable pollen grain type T1; T2 Uv PG = unviable pollen grains type 2; T3 PG = pollen grains type $3 ; \mathrm{T} 4 \mathrm{PG}=$ pollen grains type 4 . 
Table 2. Viable pollen grains percentage and unviable using fluorescein diacetate in Passiflora subrotunda as a function of different light levels and times of collection of the pollen grain.

\begin{tabular}{|c|c|c|c|c|c|c|c|c|}
\hline \multirow[b]{3}{*}{$\mathrm{H}$} & \multicolumn{4}{|c|}{ Light level (\%) } & \multicolumn{4}{|c|}{ Light level (\%) } \\
\hline & 25 & 50 & 75 & 100 & 25 & 50 & 75 & 100 \\
\hline & \multicolumn{4}{|c|}{ PG Vi (\%) } & \multicolumn{4}{|c|}{ PG Uv (\%) } \\
\hline 9 & 64.52 & 70.47 & 86.19 & 59.51 & 35.48 & 29.53 & 13.81 & 40.49 \\
\hline 10 & 65.95 & 60.02 & 43.39 & 65.38 & 34.05 & 39.98 & 56.61 & 34.62 \\
\hline 11 & 72.41 & 58.81 & 69.71 & 75.20 & 27.59 & 41.19 & 30.29 & 24.80 \\
\hline 12 & 71.14 & 91.96 & 77.30 & 60.19 & 28.87 & 8.04 & 22.70 & 39.81 \\
\hline 13 & 36.37 & 71.97 & 56.05 & 79.35 & 63.63 & 28.03 & 43.95 & 20.65 \\
\hline 14 & 81.01 & 72.11 & 66.23 & 73.25 & 18.99 & 27.89 & 33.77 & 26.75 \\
\hline 15 & 68.90 & 87.73 & 82.12 & 74.33 & 31.10 & 12.27 & 17.88 & 25.67 \\
\hline 16 & 80.17 & 86.33 & 61.89 & 77.17 & 19.83 & 13.67 & 38.11 & 22.83 \\
\hline 17 & 70.43 & 87.30 & 55.28 & 90.41 & 29.57 & 12.70 & 44.72 & 9.59 \\
\hline
\end{tabular}

PG Vi = Viable pollen grains; $\mathrm{Uv} P \mathrm{PG}=$ unviable pollen grains.

Table 3. Fertilization rate and the number of seeds in function three types pollination, open pollination, self-pollination, and hand crosspollination in Passiflora subrotunda.

\begin{tabular}{lcr}
\hline Types of pollination & $\begin{array}{c}\text { Fertilization } \\
\text { rate }\end{array}$ & $\begin{array}{r}\text { Number } \\
\text { of seeds }\end{array}$ \\
\hline Open pollination & $1.00 \mathrm{c}$ & $15.00 \mathrm{~b}$ \\
Self-pollination & $14.00 \mathrm{~b}$ & $91.00 \mathrm{~b}$ \\
Cross-pollination & $52.00 \mathrm{a}$ & $1,499.00 \mathrm{a}$ \\
\hline
\end{tabular}

Different letters in the same column indicate significant difference by the Duncan test $(P<0.05)$.

pollen viability was less than $70 \%$ throughout the period of anthesis (6:00 AM to 12:00 PM) when applying Alexander solution and fluorescein diacetate (Belo et al., 2015).

Pollen grains from $P$. subrotunda genotypes showed a positive reaction to Lugol solution, characterizing them as amylaceous. Pollen grain starch is metabolically more accessible for developing pollen tube, increasing fertilization likelihood (Souza et al., 2004a).

Stigma receptivity is an important factor for inferring the best pollen deposition period on the flower and essential for planning genetic breeding programs. Depending of the species, stigma usually produces substances that are viscous and promote pollen adhesion. This characteristic contributes to likely fertilization, with fruits and seeds formation (Silva et al., 2008). Therefore, PGs must be viable at the time the flower opens, and stigma also needs to be receptive to pollen for efficient pollination and fertilization to occurs (Souza et al., 2004b).

Long period of stigma reception increases pollination probability (Rathcke and Lacey, 1985). Depending of the species, highest stigma receptivity percentage is obtained during anthesis (Belo et al., 2015; Brito et al., 2010; Manju and Rawat, 2006). These information are important for the breeders, once the longer stigma receptivity period enable crossings to be achieved at the most suitable time (Brito et al., 2010). However, stigma receptivity was not verified in this study during all collection time. In $P$. edulis Sims f. flavicarpa, stigma receptivity was influenced by the collection time, with a reduction as the time increased (Souza et al., 2004b). In P. cincinnata Mast., stigma were found to be receptive from 4:00 AM to 5:00 PM (Kiill et al., 2010). In other species, such as Ocimum basilicum L. (Brito et al., 2010) and apple (Malus $\times$ domestica) (Losada and Herrero, 2012), stigma were found to be totally receptive at anthesis.

Environmental factors, such as temperature, can influence stigma receptivity (StiehlAlves and Martins, 2008) because many plant species are susceptible to high temperatures, especially during reproductive phase (Park et al., 1998). Thus, greater receptivity in more illuminated environment may have been influenced by that factor because $P$. subrotunda, when subjected to higher temperatures in full sun environment, obtained a higher receptivity percentage up until 1:00 PM. In lower available light conditions, most of the stigma were found to be partially receptive. From 1:00 PM, there was a reduction in receptivity; this was possibly because of the decreasing temperatures at the afternoon. In Erythronium sibiricum, receptiveness was greater under lower light availability conditions. Flowers remained open during a period between 26 to $30 \mathrm{~h}$ and in environments with more light availability, receptivity was greater $26 \mathrm{~h}$ after anthesis (Gu Li Jiang and $\mathrm{Gu} \mathrm{Li}$ Xi La, 2013). In Cajanus cajanifolius, temperature greater than $35^{\circ} \mathrm{C}$ had negatively influenced stigma receptivity (Sahai and Rawat, 2013)

Self-incompatibility has been reported in many species of Passiflora (Akamine and Girolami 1959, Conceição et al., 2011, Ocampo et al., 2016, Ramírez, 2006). Selffertilization and interspecific compatibility were verified in wild and cultivated Passiflora species (Ocampo et al., 2016). Regarding self-fertilization, self-incompatibles were observed in the following species: $P$. cincinnata, $P$. maliformis, $P$. caerulea, Passiflora mucronata, Passiflora vitifolia, $P$. edulis f. flavicarpa, and $P$. alata, and low percentage of self-pollination. In turn, Passiflora tarminiana, P. edulis f. edulis, Passiflora ligularis, and Passiflora manicata were considered as partially self-incompatible species because they presented auto-fertility between $20 \%$ and $40 \%$ (Ocampo et al., 2016). In the case of self-incompatible species, fruit production is conditioned to controlled cross-pollination, involving different species genetically compatible (Ocampo et al., 2016). High percentage of fruiting was observed in P. edulis $\mathrm{f}$. edulis from manual self-pollination and geitonogamy (pollen transference from different flowers in the same plant), when compared with self-pollination, natural pollination, and cross-pollination (Rendón et al., 2013). In consequence of floral morphology and physiology, Passiflora miniata and $P$. vitifolia are self-incompatible, providing cross-pollination (Ramírez, 2006). Thus, based on the studies involving Passiflora, it can be inferred that many species present selfincompatibility phenomenon. However, some have different degrees of compatibility; once even in low percentages, fruits are produced.

Although $P$. subrotunda presented selfincompatibility, this species produced flowers that were fertilized by self-pollination, even with low percentages. It is possible that this is a strategy used by the plant in case of crosspollination failure; i.e., the flower may have the ability to self-fertilize if pollen from another plant does not reach its stigma (Hmeljevski et al., 2007). On the other hand, this low percentage could also be explained by the flower's morphology, which has a selfpollination barrier because PG does not reach the stigma (Das et al., 2013).

Self-incompatibility is also related as being a consequence from abiotic factors such as precipitation (Rendón et al., 2013) and high temperatures (Zinn et al., 2010), suggesting that the effects of temperature are higher on pollen maturation than on germination, pollen tube growth, and fertilization (Zinn et al., 2010). In tomato, negative influence on fruiting and number of seeds were observed because of the effect of thermal stress (high temperatures) on the PG during its development and release (Peet et al., 1998).

In Passiflora, self-incompatibility is homomorphic, being controlled only by a multiallelic locus, the $S$-locus (Takayama et al., 2000). Self-incompatibility can also be determined by the action of gametophytic genes associated with sporophytic genes (Suassuna et al., 2003). Gametophytic or sporophytic self-incompatible response occurs after pollenpistil interaction. In $P$. edulis Sims., this incompatibility leads to lower pollen tube growth after $1 \mathrm{~h}$ of incompatible pollination. This occurs because PG has a similar allele as that present in the pistil (Madureira et al., 2014). After a longer period of interaction between pollen and stigma, the pollen tube causes a disorganization in the protoplasm, with a circular shape, which is unlike to the normal growth of compatible tubes (Madureira et al., 2014).

In compatible and incompatible crossings between Passiflora species performed to obtain ornamental hybrids, the growth of pollen tube presented differences. There was a spiraling of the pollen tubes on incompatible crossings and these tubes became stuck on the style. However, in the compatible crossings, the tube entered as normal through style reaching the ovary (Bugallo et al., 2011). When the $S$-allele from the mother is dominant over the father's allele, the crossing is incompatible. On the other hand, when the $S$ allele from the mother is recessive, the crossing is compatible (Brennan and Hiscock, 2010). Thus, the $S$ 
alleles also act to inhibit interspecific hybridizations (McClure et al., 2000). In P. edulis $\mathrm{f}$. flavicarpa Deg., dry-type stigma and solidtype style may be related to selfincompatibility (Souza et al., 2006).

Passiflora subrotunda presented a low percentage of self-fertility and consequently low production of fruits and seeds through open pollination. According to Junqueira et al. (2001), the absence of pollinators in agricultural field, such as the mamangava (Xylocopa spp.), which is the main pollinated agent of passion fruit, can be related to the use of agricultural pesticides. In our observation, rainfall season also indicated the absence of pollinators affecting natural pollination (V.O. Souza, personal observation).

The study of $P$. subrotunda genotypes allows the knowledge of characteristics that interest the market of ornamental plants, such as flowers opening period, and vast flowering in environments with greater availability of light. In addition, it was possible the knowledge of aspects related to the reproduction system and the most appropriate period for the realization of controlled pollinations. These results help in the identification of interest characteristics and it will support in planning breeding programs using $P$. subrotunda.

\section{Literature Cited}

Abreu, P.P., M.M. Souza, E.A. Santos, M.V. Pires, M.M. Pires, and A-A.F. Almeida. 2009. Passion flower hybrids and their use in the ornamental plant market: Perspectives for sustainable development with emphasis on Brazil. Euphytica 166:307-315.

Akamine, E.K. and G. Girolami. 1959. Pollination and fruit set in yellow passion fruit. Hawaii Agr. Expt. Sta., Univ. Hawaii, Tech. Bul. 39.

Alexander, M.P. 1969. Differential staining of aborted and non-aborted pollen. Stain Technol. 44:117-122.

Amela-García, M.T., B.G. Galati, and A.M. Anton. 2002. Microsporogenesis, microgametogenesis and pollen morphology of Passiflora spp. (Passifloraceae). Bot. J. Linn. Soc. 139:383394.

Arias, J.C., J. Ocampo, and R. Urrea. 2016. Pollination systems in sweet granadilla (Passiflora ligularis Juss.) as a basis for genetic and conservation studies. Acta Agron. 65:197-203.

Belo, G.O. 2010. Análise morfológica e genética em progênie hibrida F1 do cruzamento Passiflora gardneri MAST $\times$ Passiflora gibertii N.E. BROW. State Univ. Santa Cruz, Diss.

Belo, G.O., M.M. Souza, V.O. Souza, and C.A.F. Melo. 2015. Reproductive and cytogenetic characterization in Passiflora sublanceolata. Biologia 70:733-743.

Bernacci, L.C., A.C. Cervi, M.A. Milward-DeAzevedo, T.S. Nunes, D.C. Imig, and A.C. Mezzonato. 2013. Lista de Espécies da Flora do Brasil. Jardim Botânico do Rio de Janeiro. 12 May 2014. <http://floradobrasil.jbrj.gov.br/ jabot/listaBrasil $>$.

Borém, A. and G.V. Miranda. 2009. Melhoramento de plantas. 4th ed. Viçosa.

Brennan, A.C. and S.J. Hiscock. 2010. Expression and inheritance of sporophytic self-incompatibility in synthetic allohexaploid Senecio cambrensis (Asteraceae). New Phytol. 186:251-261.

Brito, A.C., J.D. Souza, T.N.H. Rebouças, and C.L.F. Amaral. 2010. Propriedades do pólen e do estigma de Ocimum basilicum L. (cultivar
Maria Bonita) para aumentar a eficiência de cruzamentos em programas de melhoramento. Rev. Bras. Plantas Med. 12:208-214.

Bruckner, C.H., V.W.D. Casali, C.F. de Moraes, A.J. Regazzi, and E.A.M. Silva. 1995. Selfincompatibility in passion fruit (Passiflora edulis Sims). Acta Hort. 370:45-57.

Brazil plants_Plantae Brasilis. Dec. 2017. <https:// www.brazilplants.com/menu.html>.

Bugallo, V., S. Cardone, M.J. Pannunzio, and G. Facciuto. 2011. Breeding advances in Passiflora spp. (Passionflower) native to Argentina. Floriculture Ornamental Biotechnol. 5:23-34.

Cavichioli, J.C., C. Ruggiero, C.A. Volpe, E.M Paulo, J.L. Fagundes, and F.S. Kasai. 2006. Florescimento e frutificação do maracujazeiroamarelo submetido à iluminação artificial, irrigação e sombreamento. Rev. Bras. Frutic. 28:92-96.

Conceição, L., M.M. Souza, G.O. Belo, S.F Santos, and J. Freitas. 2011. Hybridization among wild passionflower species. Rev. Bras. Bot. 34:237-240.

Costa, R.S., F.V. Moro, and J.C. Oliveira. 2009. Influência do momento de coleta sobre a viabilidade de grão de pólen em maracujá-doce (Passiflora alata Curtis). Rev. Bras. Frutic. 31:956-961.

Cruden, R.W. and S. Miller-Ward. 1981. Pollenovule ratio, pollen size, and the ratio of stigmatic area to the pollen-bearing area of the pollinator: An hypothesis. Evolution 35:964974.

Cruz, M.C.M., D.L. Siqueira, L.C.C. Salomão, and P.R. Cecon. 2006. Florescimento da tangerina 'Ponkan'e da limeira ácida 'Tahiti' submetidas ao estresse hídrico. Rev. Bras. Frutic. 28:360364.

Dafni, A. 1992. Pollination ecology: A practical approach. Oxford University Press, New York, NY.

Das, M.R., T. Hossain, M.A. Baset Mia, J.U. Ahmed, A.J.M. Sirajul Karim, and M. Mofazzal Hossain. 2013. Fruit setting behaviour of passion fruit. Amer. J. Plant. Sci. 4:1066-1073.

Defani-Scoarize, M.A., M.S. Pagliarini, and C.G. Aguiar. 1995. Evolution of meiotic behavior in double-cross maize hybrids and their parentes. Maydica 40:319-324.

Dias-Filho, M.B. 1997. Physiological response of Solanum crinitum Lam. to contrasting light environments. Pesqui. Agropecu. Bras. 32:789-796.

Dousseau, S., A.A. Alvarenga, M.O. Santos, and L.O. Arantes. 2007. Influência de diferentes condições de sombreamento sobre o crescimento de Tapirira guianensis Alb. Rev. Bras. Biocienc. 5:77-479.

Erdtman, G. 1945. Pollen morphology abd plant taxonomy. III. Morina L. With an addition on pollen morphological terminology. Svensk Bot. Tidskr. 39:279-285.

Erdtman, G. 1952. Pollen morphology and plant taxonomy angiosperms. Almqvist \& Wiksell, Stockholm, Sweden.

Erdtman, G. 1986. Pollen morphology and plant taxonomy: An introduction to palynology. Almqvist e Wiksell, Stockholm, Sweden.

Evaldt, A.C.P., S.G. Bauermann, R.R. Cancelli, M. Acioli, and P.C.P. Neves. 2011. Morfologia polínica de Passifloraceae Juss. ex Kunth. no Rio Grande do Sul, Brasil. R. Bras. Bioc. 9:7587.

Faegri, K. and J. Iversen. 1964. Textbook of pollen analysis. Blackwell, Oxford.

Ferreira, M.A.J.F., M.A. Queiroz, R. Vencovsky, L.T. Braz, and M.L.C. Vieira. 2004. Implicações da expressão sexual e do sistema reprodutivo de melancia em programa de pré-melhoramento. Bol. Pesqui. Desenvolvimento 65:24.

Galen, C. and R.C. Plowright. 1987. Testing the accuracy of using peroxidase activity to indicate stigma receptivity. Can. J. Bot. 65:107111.

Gu Li Jiang, J.M.B. and S.P.X. Gu Li Xi La. 2013. Effects of different light conditions on pollen viability stigma receptivity of Erythronium sibiricum. J. South. Agr. 44:1444-1447.

Heslop-Harrison, J. and Y. Heslop-Harrison. 1970. Evaluation of pollen viability by enzymatically induced fluorescence; intracellular hydrolysis of fluorescein diacetate. Stain Technol. 45:115-120.

Hmeljevski, K.V., A. Reis, M.S. Reis, J.M. Rogaslski, C.D. Neto, and M. Lenzi. 2007. Resultados preliminares da biologia reprodutiva de Dyckia ibiramensis Reitz (Bromeliaceae): Uma espécie rara e endêmica de Santa Catarina. Rev. Bras. Biocienc. 5:267-269.

Hopkins, W.G. 1999. Introduction to plant physiology. 4th ed. Wiley, Chichester.

Iversen, J. and J. Troels-Smith. 1950. Pollenmorfologiske definitioner og typer/pollenmorfologischer definitionen und typen. Dan. Geol. Unders. IV. Række 3/8:1-52. Copenhagen.

Johansen, D.A. 1940. Plant microtechnique. McGraw Hill, New York, NY.

Junqueira, N.T.V., M.C.M. Veras, A.C. Nascimento, R.C. Chaves, A.P. Matos, and K.P. Junqueira. 2001. Importância da polinização manual para aumentar a produtividade do maracujazeiro, primeira ed. Embrapa Cerrados, Planaltina.

Kearns, C.A. and D. Inouye. 1993. Techniques for pollinations biologists. University Press of Colorado, Niwot, CO.

Kiill, L.H.P., K.M.M. Siqueira, F.P. Araújo, S.P.M. Trigo, E.A. Feitoza, and I.B. Lemos. 2010. Biologia reprodutiva de Passiflora cincinnata MAST. (Passifloraceae) na região de Petrolina (Pernambuco, Brazil). Oecol. Austral. 14:115127.

Lawinscky, P.R., M.M. Souza, G.O. Belo, A.J.C Viana, C.A.F. Melo, and C.S.L. Oliveira. 2014. Morphological characterization and genetic diversity in Passiflora alata Curtis and P. cincinnata Mast. (Passifloraceae). Braz. J. Bot. 3:261-272.

Losada, J.M. and M. Herrero. 2012. Arabinogalactanprotein secretion is associated with the acquisition of stigmatic receptivity in the apple flower. Ann. Bot. 110:573-584.

Madureira, H.C., T.N.S. Pereira, M. Cunha, D.E. Klein, M.V.V. Oliveira, L. Mattos, and G.A. Souza Filho. 2014. Self-incompatibility in passion fruit: Cellular responses in incompatible pollinations. Biologia 69:574-584.

Manju, I. and S.S. Rawat. 2006. Studies on floral biology of Kagzi lime (Citrus aurantifolia Swingle) under valley conditions of Garhwal Himalaya. Adv. Plant Sci. 19:11-17.

MAPA-Ministério da Agricultura, Pecuária e Abastecimento. 2008. Instruções para execução dos ensaios de distinguibilidade, homogeneidade e estabilidade de cultivares de Passiflora. 18 Apr. 2012. <http:/www.agricultura.gov.br>.

Martins, K.C., S.A.M. Souza, T.N.S. Pereira, R. Rodrigues, M.G. Pereira, and M. Cunha. 2013. Palynological characterization and genetic divergence between accessions of chilli and sweet peppers. Hort. Bras. 31:568-573.

McClure, B.A., F. Cruz-García, B. Beecher, and W. Sulaman. 2000. Factors affecting inter- and intra-specific pollen rejection in Nicotiana. Ann. Bot. 85:113-123.

Meletti, L.M.M., R.R. Santos, and K. Minami. 2000. Melhoramento do maracujazeiro amarelo: 
Obtenção do 'Composto IAC-27'. Sci. Agr. 57:491-498

Meletti, L.M.M., M.D. Soares-Scott, C.A.F. PintoMaglio, and F.P. Martins. 1992. Caracterização de germoplasma de maracujazeiro (Passiflora sp.). Rev. Bras. Frutic. 14:157-162.

Munsell, A.H. 1981. A color notation. A Division of Kollmorgen Coporation, Baltimore, MD.

Nass, L.L. and E. Paterniani. 2000. Pre-breeding: A link between genetic resources and maize breeding. Sci. Agr. 57:581-587.

Negreiros, J.R.Da. S., C.H. Bruckner, C.D. Cruz, V.De. S. Álvares, M.A.D. Morgado, and D.L. Siqueira. 2007. Diversidade genética entre progênies de maracujazeiro amarelo baseado em características morfo agronômicas. Rev. Ceres 54:153-160.

Ocampo, J., J.C. Arias, and R. Urrea. 2016. Interspecific hybridization between cultivated and wild species of genus Passiflora L. Euphytica 209:395-408.

Ocampo, J. and G. Coppens d'Eeckenbrugge. 2017. Morphological characterization in the genus Passiflora L.: An approach to understanding its complex variability. Plant Syst. Evol. 305:531-558.

Oliveira, J.C. 1987. Melhoramento genético, p. 218-46. In: C. Ruggiero (ed.). Cultura do maracujazeiro. L. Summa, Ribeirão Preto.

Paiva, C.L., R.J. Guimarães, and C.A.S. Souza. 2003. Influência de diferentes níveis de sombreamento sobre o crescimento de mudas de cafeeiro (Coffea arabica L.). Ciênc. Agrotec. 27:134-140.

Park, B.H., N. Oliveira, and S. Pearson. 1998. Temperature affect growth and flowering of the balloon flower [Platycodon grandiflorus (Jack) A.DC. cv. 'Astra Blue']. HortScience 33:233-236

Passiflora Society International. Oficial PSI ICRA cultivares registradas. Passiflora Cultivars (20082010). Feb. 2014. <http://www.passionflow.co. uk/reg.htm; http://www.passiflorasociety.org >.

Passos, E.E.M. 1997. Ecofisiologia do Coqueiro, p. 65-72. In: J.M.S. Ferreira, D.R.N. Warwick, and L.A. Siqueira (eds.). Cultura do coqueiro no Brasil. Embrapa-SPI, Aracaju.

Peet, M.M., S. Sato, and R.G. Gardner. 1998. Comparing heat stress effects on male-fertile and male-sterile tomatoes. Plant Cell Environ. 21:225-231.

Peixoto, M. 2005. Problemas e perspectivas do maracujá ornamental, p. 458-462. In: F.G. Faleiro, N.T.V. Junqueira, and M.F. Braga (eds.). Maracujá germoplasma e melhoramento genético. Embrapa Cerrados, Planaltina, DF.

Pires, M.V., A-A.F. Almeida, A.L. Figueiredo, F.P. Gomes, and M.M. Souza. 2011. Photosynthetic characteristics of ornamental passion flowers grown under different light intensities. Photosynthetica 49:593-602.

Pires, M.V., A-A.F. Almeida, A.L. Figueiredo, F.P. Gomes, and M.M. Souza. 2012. Germination and seedling growth of ornamental species of
Passiflora under artificial shade. Acta Sci. Agron. 34:67-75.

Ramírez, W. 2006. Hibridación interespecífica en Passiflora (Passifloracea), mediante polinización manual, y características florales para la polinización. Lankesteriana 6:123-131.

Rathcke, B. and E.P. Lacey. 1985. Phenological patterns of terrestrial plants. Ann. Rev. Ecol. Syst. 16:179-214.

Rendón, J.S., J. Ocampo, and R. Urrea. 2013. Estudio sobre polinización y biología floral en Passiflora edulis f. edulis Sims, como base para el premejoramiento genético. Acta Agron. 62:232-241.

Sahai, K. and K.K. Rawat. 2013. Thermo-sensitive flowering behaviour of Cajanus cajanifolius (Haines) Maesen-A threatened wild relative of Cajanus cajan. Nat. Sci. 11:21-25.

Sales, J.F., J.E.B.P. Pinto, P.H. Ferri, F.G. Silva, C.B.A. Oliveira, and P.P. Botrel. 2009. Influência do nível de irradiância no crescimento, produção e composição química do óleo essencial de hortelã-do-campo (Hyptis marrubioides Epl.). Semina Ciênc. Agrar. 30:389-396.

Santos, E.A., M.M. Souza, P.P. Abreu, L.D.C.S. Conceição, I.S. Araújo, A-A.F. Almeida, A.P. Viana, and J.C.O. Freitas. 2012a. Confirmation and characterization of interspecific hybrids of Passiflora L. (Passifloraceae) for ornamental use. Euphytica 184:389-399.

Santos, E.A., M.M. Souza, A.P. Viana, A-A.F. Almeida, I.S. Araújo, and J.C.O. Freitas. 2012b. Development and bloom in hybrids of wild passion fruit cultivated in different types of pots and shading levels. Sci. Agr. 69:126-134.

Santos, E.A., M.M. Souza, A.P. Viana, A-A.F. Almeida, J.C.O. Freitas, and P.R. Lawinscky. 2011. Multivariate analysis of morphological characteristics of two species of passion flower with ornamental potential and of hybrids between them. Genet. Mol. Res. 10:2457-2471.

Silva, R.M., M.I.F.F. Gerhard Bandel, and O.S. Martins. 2001. Biologia reprodutiva de etnovariedades de mandioca. Sci. Agr. 58:101-107.

Silva, A.B., M.F. Souza, A.H.B. Silva, O.S Almeida, A.B. Silva, and L.F.A. Amaral. 2008. Biologia floral e mecanismos reprodutivos de Ocimum canum Sims (Lamiaceae). Biotemas 21:33-40.

Singh, R.J. 2002. Plant cytogenetics, 2nd ed. Taylor \& Francis Group, Boca Raton, NY.

Souza, M.M. and T.N. Pereira. 2011. Meiotic behavior in wild and domesticated species of Passiflora. Braz. J. Bot. 34:63-72.

Souza, M.M., T.M.S. Pereira, A.J.B. Dias, B.F. Ribeiro, and A.P. Viana. 2006. Structural, hystochemical and cytochemical characteristics of the stigma and style in Passiflora edulis $\mathrm{f}$ flavicarpa (Passifloraceae). Braz. Arch. Biol. Technol. 49:93-98.

Souza, M.M., T.N.S. Pereira, and E.R. Martins. 2002. Microsporogênese e microgametogênese associadas ao tamanho do botão floral e da antera e viabilidade polínica em maracujazeiro-amarelo
(Passiflora edulis Sims f. flavicarpa Degener). Ciênc. Agrotec. 6:1209-1217.

Souza, M.M., T.N. Pereira, A.P. Viana, M.G. Pereira, A.T. Amaral Júnior, and H.C. Madureira. 2004b. Flower receptivity and fruit characteristics associated to time of pollination in the yellow passion fruit Passiflora edulis Sims f. flavicarpa Degener (Passifloraceae). Scientia Hort. 101:373-385.

Souza, M.M., T.N. Pereira, A.P. Viana, L.C. Silva, and C.P. Sudré. 2004a. Pollen viability and fertility in wild and cultivated Passiflora species (Passifloraceae). Beitr. Biol. Pflanz. 73:118.

Stiehl-Alves, E.M. and M.P. Martins. 2008. Biologia reprodutiva de Acacia mearnsii de wild.: receptividade de estigmas. Rev. Árvore 32:609-616.

Suassuna, T.M.F., C.H. Bruckner, C.R. Carvalho, and A. Borém. 2003. Self-incompatibility in passion fruit: Evidence of gametophyticsporophytic control. Theor. Appl. Genet. 106: 298-302.

Taiz, L. and E. Zeiger. 2013. Fisiologia Vegetal. 5th ed. Artmed, São Paulo.

Takayama, S., H. Shiba, M. Iwano, H. Shimosato, F-S. Che, N. Kai, M. Watanabe, G. Suzuki, K. Hinata, and A. Isogai. 2000. The pollen determinant of self-incompatibility in Brassica campestris. Proc. Natl. Acad. Sci. USA 97:1920-1925.

Tombolato, A.F.C., R.F.A. Veiga, W. Barbosa, A.A. Costa, R. Benatti Júnior, and E.G. Pires. 2004. Domesticação e pré- melhoramento de plantas: I. Ornamentais. O Agronômico, Campinas 56:12-14.

Twell, D. 1995. Diphtheria toxin-mediated cell ablation in developing pollen: Vegetative cell ablation blocks generative cell migration. Protoplasma 187:144-154.

Ulmer, T. and J.M. MacDougal. 2004. Passiflora: Passionflowers of the world. Timber Press, Portland.

Valladares, F. and U. Niinemets. 2008. Shade tolerance, a key plant feature of complex nature and consequences. Annu. Rev. Ecol. Evol. Syst. 39:237-257.

Valls, J.F.M. 2007. Caracterização de recursos genéticos vegetais, p. 281-305. In: L.L. Nass (ed.). Recursos genéticos vegetais. Brasília, DF: Embrapa Recursos Genéticos e Biotecnologia.

Vanderplank, J. 2000. Passion flowers. The MIT Press, Cambridge.

Varela, V.P. and J. Santos. 1992. Influência do sombreamento na produção de mudas de angelim-pedra (Dinizia excelsa Ducke). Acta Amazon. 22:407-411.

Zapata, T.R. and M.T.K. Arroyo. 1978. Plant reproductive ecology of a secondary deciduous tropical forest in Venezuela. Biotropica 40:221-230.

Zinn, K.E., M. Tunc-Ozdemir, and J.F. Harper. 2010. Temperature stress and plant sexual reproduction: Uncovering the weakest links. J. Expt. Bot. 61:1959-1968. 
Supplemental Table 1. Analysis summary variance of vegetative characteristics of genotypes 1 and 2 of Passiflora subrotunda for different light levels, types of pot, and evaluation periods.

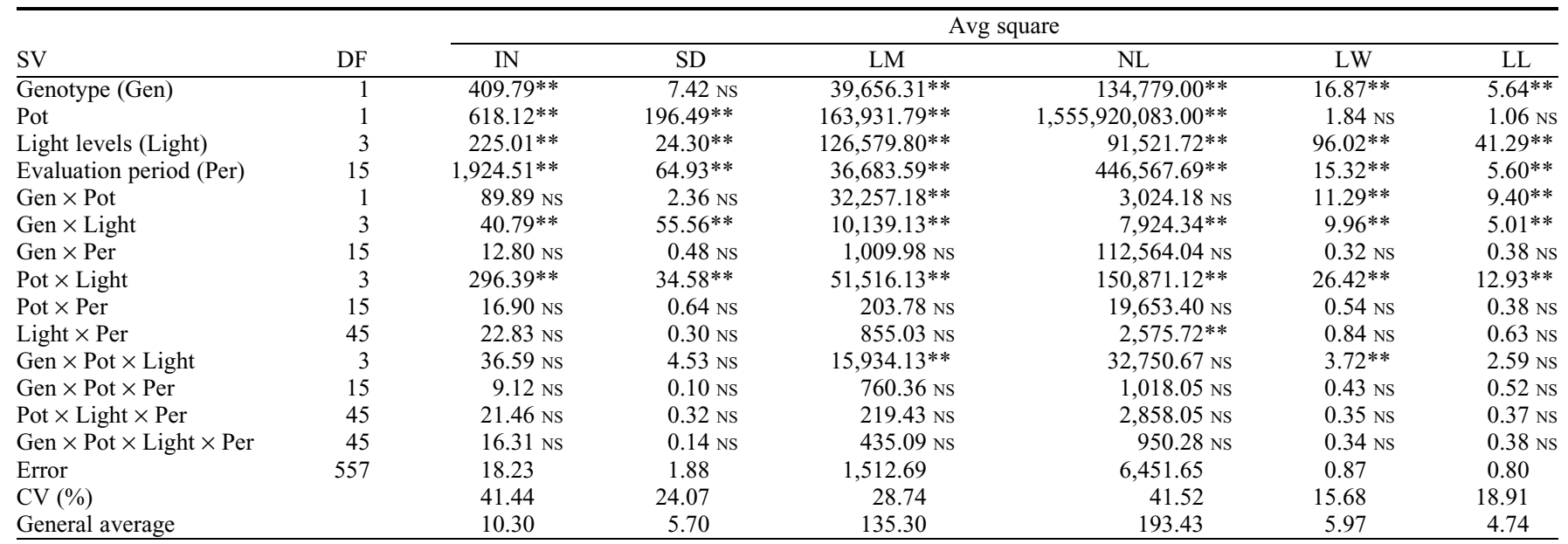

$\mathrm{SV}=$ source of variation; $\mathrm{DF}=$ degree of freedom; $\mathrm{CV}=$ coefficient of variation; $\mathrm{IN}=$ internodes number; $\mathrm{SD}=$ stem diameter in $\mathrm{mm}$; $\mathrm{LM}=$ length of the main branch in $\mathrm{cm} ; \mathrm{NL}=$ number of leaves per plant; $\mathrm{LW}=$ leaf width in $\mathrm{cm} ; \mathrm{LL}=$ leaf length in $\mathrm{cm}$.

NS, ${ }^{* *}$ Not significant test at $P \leq 0.01$.

Supplemental Table 2. Analysis summary variance of floral characteristics genotypes 1 and 2 of Passiflora subrotunda for different shading levels and types of pot.

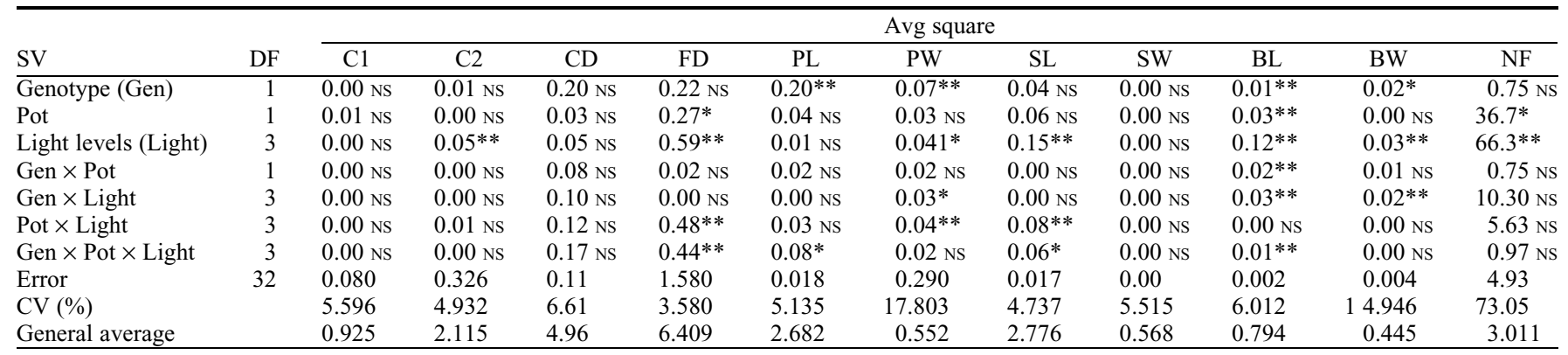

$\mathrm{SV}=$ source of variation; $\mathrm{DF}=$ degree of freedom; $\mathrm{CV}=$ coefficient of variation; $\mathrm{C} 1=$ the length of the corona internal filaments in $\mathrm{cm} ; \mathrm{C} 2=$ long filaments of external corona in $\mathrm{cm} ; \mathrm{CD}=$ corona diameter in $\mathrm{mm} ; \mathrm{FD}=$ flower diameter in $\mathrm{mm} ; \mathrm{PL}=$ petal length in $\mathrm{cm} ; \mathrm{PW}=$ petal width in $\mathrm{cm} ; \mathrm{SL}=$ sepal length in $\mathrm{cm} ; \mathrm{SW}=$ sepal width in $\mathrm{cm} ; \mathrm{BL}=$ bract length in $\mathrm{cm} ; \mathrm{BW}=$ bract width in $\mathrm{cm} ; \mathrm{NF}=$ number of flowers $/$ plant.

Ns, ${ }^{*},{ }^{* *}$ Not significant test at $P \leq 0.05, P \leq 0.01$.

Supplemental Table 3. Analysis summary variance of pollen viability of Passiflora subrotunda with Alexander solution, and fluorescein diacetate and stigma receptivity using tests hydrogen peroxide, according to different light levels and times of collection of the pollen grain.

\begin{tabular}{|c|c|c|c|c|c|c|c|c|c|}
\hline \multirow[b]{2}{*}{ SV } & \multirow[b]{2}{*}{ DF } & \multicolumn{5}{|c|}{ Alexander solution } & \multicolumn{2}{|c|}{ Fluorescein diacetate } & \multirow{2}{*}{$\frac{\text { Stigma receptivity }}{R E}$} \\
\hline & & Vi PG & Uv T1 PG & Uv T2 PG & T3 PG & T4 PG & Vi PG & Uv PG & \\
\hline Hours & 8 & $0.514 \mathrm{NS}$ & $0.167 \mathrm{NS}$ & $0.042 \mathrm{NS}$ & $0.173 \mathrm{NS}$ & $0.008 \mathrm{NS}$ & $576.960 *$ & $576.904 *$ & $2,241.030^{*}$ \\
\hline CV $(\%)$ & & 0.84 & 63.73 & 69.58 & 93.85 & 98.91 & 23.20 & 56.39 & 41.53 \\
\hline General average & & 98.35 & 0.94 & 0.23 & 0.38 & 0.08 & 70.84 & 29.15 & 61.57 \\
\hline
\end{tabular}

$\mathrm{SV}=$ source of variation; $\mathrm{DF}=$ degree of freedom; $\mathrm{CV}=$ coefficient of variation; $\mathrm{PG} \mathrm{Vi}=$ viable pollen grains; $\mathrm{Uv}$ PG $=$ unviable pollen grain ; T1 Uv $\mathrm{PG}=$ unviable pollen grain type T1; T2 Uv PG = unviable pollen grain type 2; T3 PG = pollen grain type 3; $\mathrm{T} 4 \mathrm{PG}=$ pollen grain type 4; RE = receptivity .

Ns, *Not significant by F test at $P \leq 0.05$.

Supplemental Table 4. Analysis summary variance of the fertilization rate and the number of seeds resulting from three types of pollination, open pollination, self-pollination, and cross-pollination, genotypes 1 and 2 of Passiflora subrotunda.

\begin{tabular}{lccc}
\hline & & \multicolumn{2}{c}{ Mean Square } \\
\cline { 3 - 4 } SV & DF & Fertilization rate & Number of seeds \\
\hline Genotype (Gen) & 1 & $1.3611 \mathrm{NS}$ & $420.2500 \mathrm{NS}$ \\
Pollination type (PT) & 2 & $58.5277^{* *}$ & $50,445.7777^{* * *}$ \\
Gen $\times$ PT & 2 & $2.1944 \mathrm{NS}$ & $1,737.3333 \mathrm{Ns}$ \\
Error & 30 & 0.7833 & 789.8388 \\
CV $(\%)$ & & 47.56 & 67.23 \\
General average & 1.86 & 41.80 \\
\hline
\end{tabular}

$\mathrm{SV}=$ source of variation; $\mathrm{DF}=$ degree of freedom; $\mathrm{CV}=$ coefficient of variation.

${ }^{\mathrm{NS},}{ }^{* *}$ Not significant by $\mathrm{F}$ test at $P \leq 0.01$. 


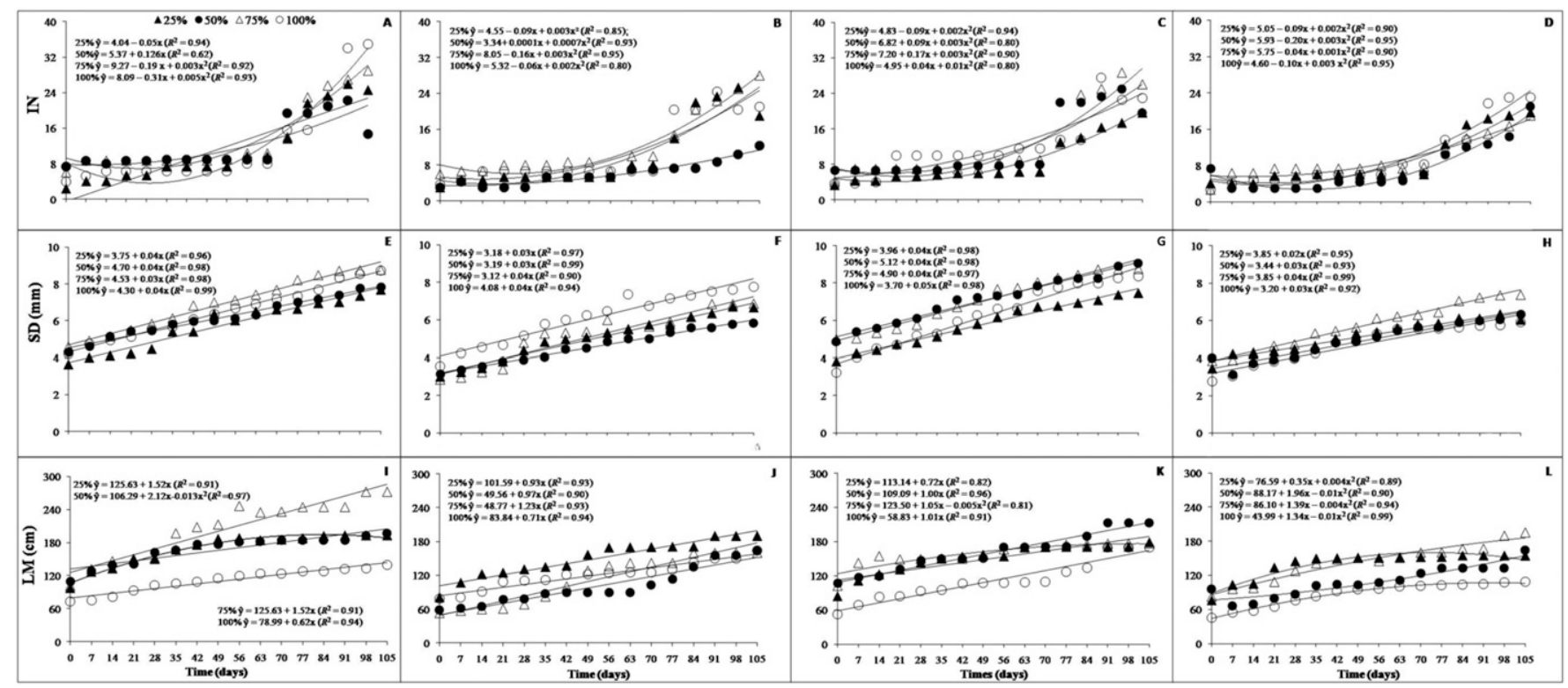

Supplemental Fig. 1. Passiflora subrotunda: internodes number (IN) from the largest branch of genotype 1 cultivated in concrete pots (A) and ceramic pots (B) and of genotype 2 cultivated in concrete pots $(\mathbf{C})$ and ceramic pots (D), stem diameter (SD) of the largest branch of genotype 1 cultivated in concrete pots $(\mathbf{E})$ and ceramic pots $(\mathbf{F})$ and of genotype 2 cultivated in concrete pots $(\mathbf{G})$ and ceramic pots $(\mathbf{H})$, and main branch length (LM) of genotype 1 cultivated in concrete pots $(\mathbf{I})$ and ceramic pots $(\mathbf{J})$ and of genotype 2 cultivated in concrete pots $(\mathbf{K})$ and ceramic pots $(\mathbf{L})$ submitted to different light levels.

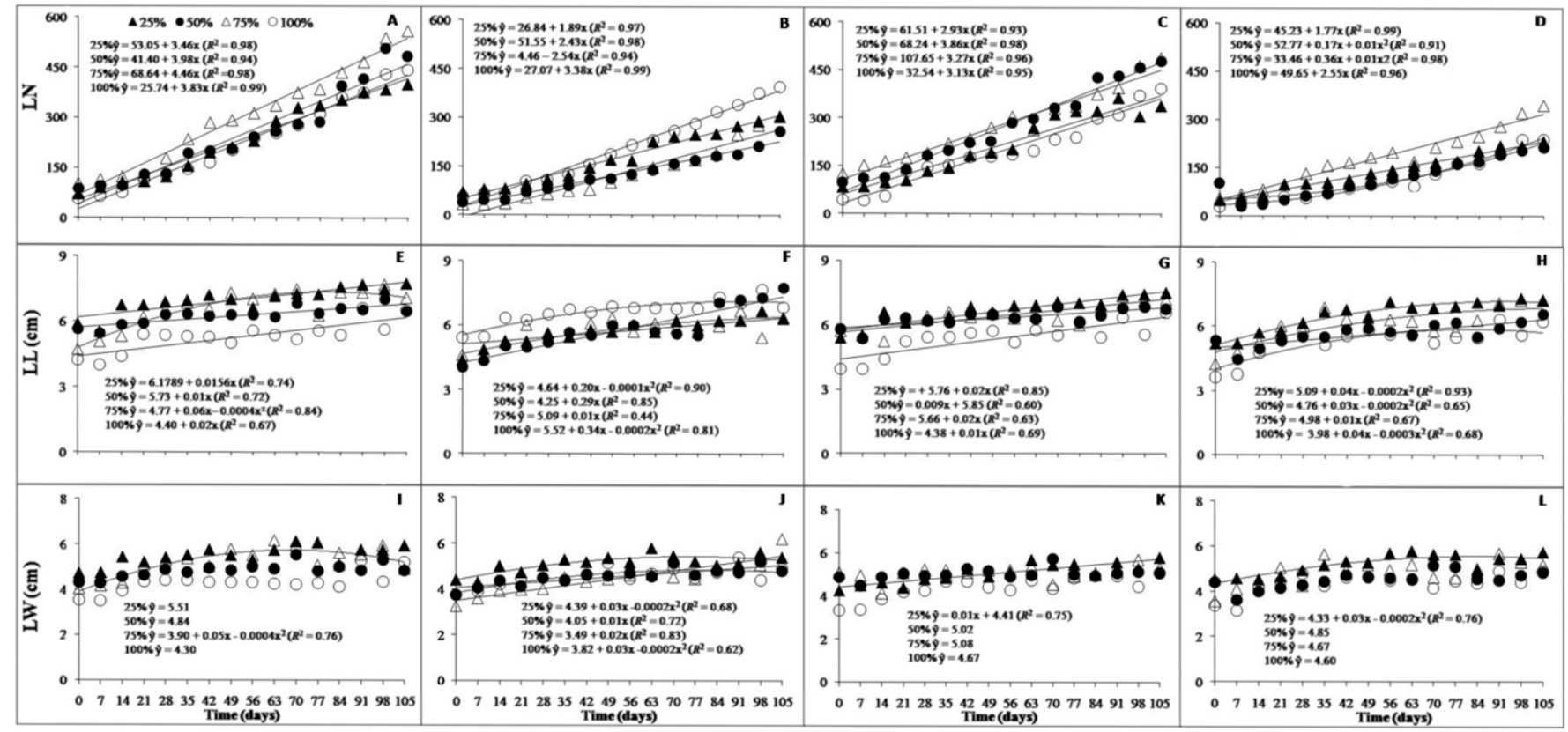

Supplemental Fig. 2. Passiflora subrotunda: leaf numbers (LN) of genotype 1 cultivated in concrete pots (A) and ceramic pots (B) and of genotype 2 cultivated in concrete pots (C) and ceramic pots (D), leaf length (LL) of genotype 1 cultivated in concrete pots (E) and ceramic pots (F) and of genotype 2 cultivated in concrete pots $(\mathbf{G})$ and ceramic pots $(\mathbf{H})$, width leaf $(\mathrm{WL})$ of genotype 1 cultivated in concrete pots $(\mathbf{I})$ and ceramic pots $(\mathbf{J})$ and of genotype 2 cultivated in concrete pots $(\mathbf{K})$, and ceramic pots $(\mathbf{L})$ subjected to different light levels. 


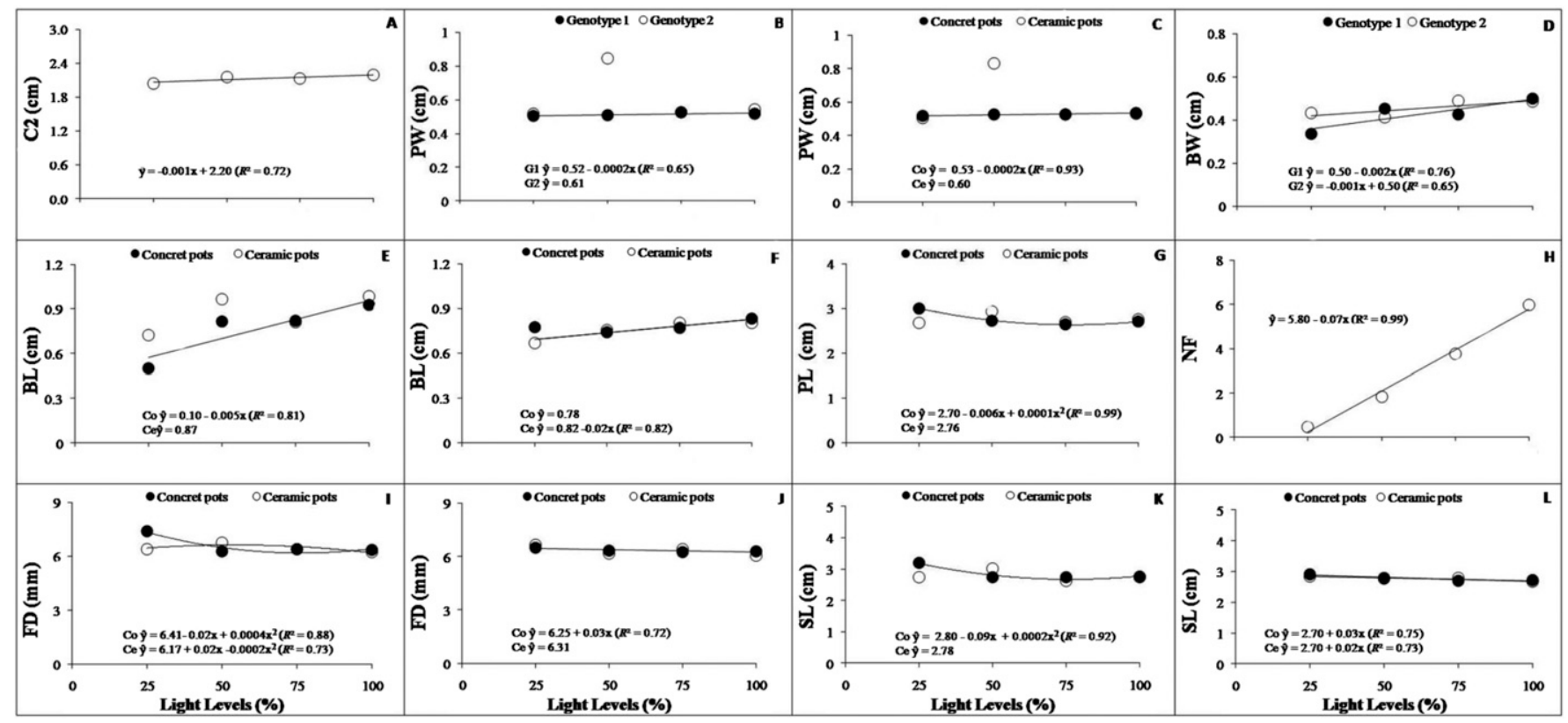

Supplemental Fig. 3. Passiflora subrotunda: length of external filament of the corona (C2) (A), petal width of genotype 1 (B) and genotype 2 cultivated in concrete pots and ceramic pots (C), bract width (BW) of genotype 1 and genotype $2(\mathbf{D})$, bract length (BL)of genotype 1 in a concrete pot and in a ceramic pot (E) and of genotype 2 in a concrete pot and in a ceramic pot (F), petal length (PL) of genotype 1 in a concrete pot and in a ceramic pot (G), number of flowers per plant $(\mathrm{NF})(\mathbf{H})$, flower diameter (FD) of genotype 1 in a concrete pot and in a ceramic pot (I) and of genotype 2 in a concrete pot and in a ceramic pot (J), and sepal length (SL)of genotype 1 in a concrete pot and in a ceramic pot (K) and of genotype 2 in a concrete pot and in a ceramic (L) pot subjected to different light levels. $\mathrm{PW}=$ petal width.

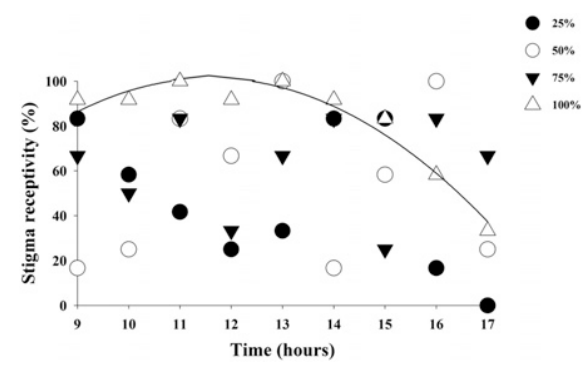

Supplemental Fig. 4. Stigma receptivity of Passiflora subrotunda subjected to different light levels and stigma collection times. $25 \hat{\mathrm{y}}=0.23$, $50 \hat{y}=0.27,75 \hat{y}=0.02$, and $100 \hat{y}=-2.201 \times 2+$ $51.11 \mathrm{x}-195.4\left(R^{2}=0.94\right)$. 